\title{
Connessioni temporali: lettura critica di un progetto in tre tempi
}

\author{
Daniela Palomba \\ Sabrina Acquaviva \\ Marika Falcone
}

Abstract

I| saggio presenta uno studio condotto su Casa Piscitelli un edificio residenziale borghese realizzato a Napoli nel quartiere Chiaia, alla metà del secolo scorso. Per la sua progettazione vennero coinvolti diversi architetti tra i più illustri protagonisti del panorama partenopeo.

Tre i progetti che raccontano il gusto, le sperimentazioni e i caratteri compositivi che qualificarono il linguaggio architettonico di quegli anni. Tre progettisti che si trovarono, in momenti differenti, ad interpretare le richieste di una stessa committenza: Chiaromonte, de Luca e Mustica. Lo studio condotto parte dalla lettura dei disegni d'archivio dei progetti non realizzati, quei progetti "esempi di cose ... che mai saranno" che vengono indagati e messi a confronto con la configurazione dell'opera realizzata. Il tema del confronto tra le diverse interpretazioni di uno stesso progetto suggerisce di individuare e/o verificare eventuali relazioni tra le idee, di tessere e annodare possibili rapporti, di riconoscere diversità e analogie. Questi processi conoscitivi, quando riferiti ad architetture non più esistenti o mai realizzate, si possono avverare grazie al disegno, alla documentazione iconografica esistente, per essere poi raccontati ed esplicitati anche attraverso nuove figurazioni.
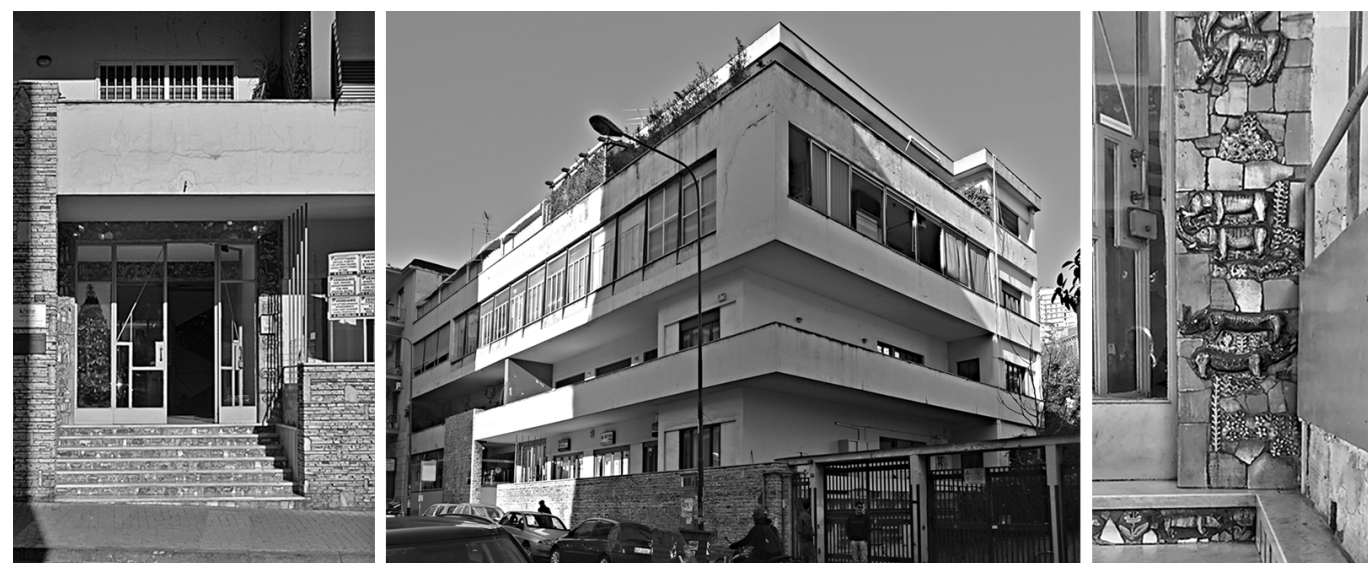


\section{Introduzione}

II disegno nelle sue diverse connotazioni forma ed esplicita il pensiero e l'immagine dell'architettura, connotandosi quale linguaggio attraverso cui il reale si rende manifesto nella sua fisicità e nella storia del suo divenire. Nella narrazione dell'architettura, il disegno costituisce infatti il supporto visivo di un racconto che si svolge nel tempo, essendo capace di documentarne non solo le trasformazioni, ma anche le potenziali esistenze che si sono palesate nel tempo, riannodando le diverse figurazioni e consentendo di porre su un unico piano del confronto linguaggi e specificità espressive.

In questo ambito di riflessioni è parso di interesse esaminare un caso studio le cui figurazioni si sono moltiplicate nel tempo e la cui rappresentazione si offre quale dispositivo teorico/ grafico capace di creare connessioni inedite, esplicitando analogie e differenze che si rendono evidenti sul piano del confronto. Si tratta di un edificio che ricade in una delle zone di espansione che ha interessato la città di Napoli nella prima metà del $X X$ secolo e che è stato occasione di sperimentazione progettuale da parte di alcuni protagonisti della scena architettonica napoletana di quegli anni.

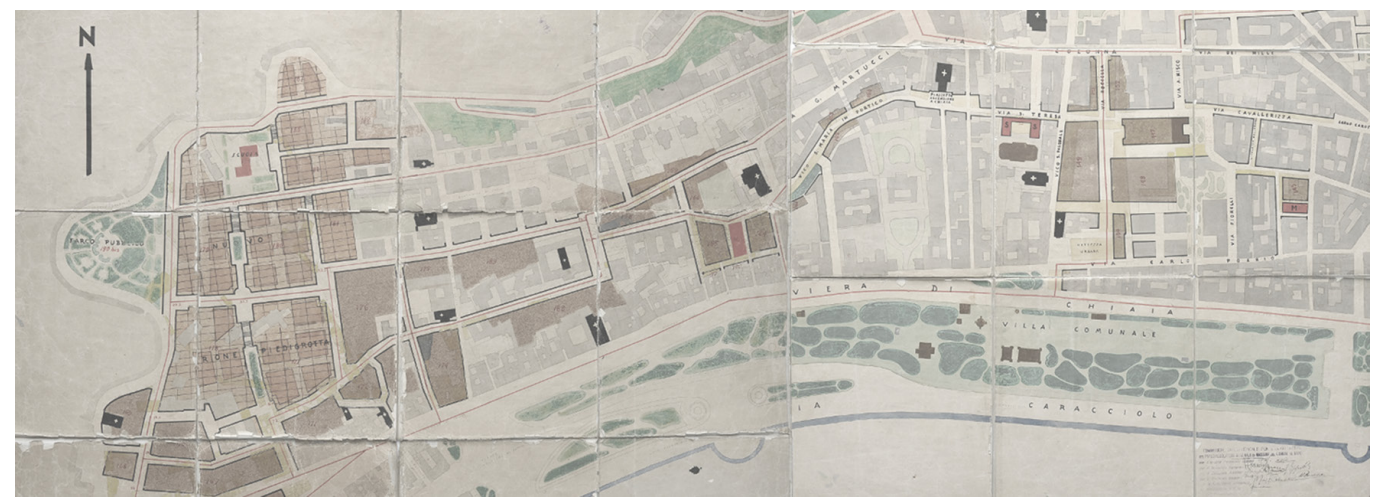

\section{L'architettura napoletana tra i due conflitti mondiali}

Alla vigilia del secondo conflitto mondiale, dopo un ventennio di regime fascista e con decenni di ritardo rispetto ad altre città italiane, Napoli viveva un nuovo fervore edilizio con la costruzione di nuovi edifici ed interi quartieri residenziali. Questa importante attività edilizia aveva avuto inizio nel I 885 con la legge per il Risanamento nell'ambito del quale erano stati programmati interventi volti alla bonifica edilizia, alla realizzazione dei servizi collettivi e al riordino della rete stradale. Come è noto, a causa dell'endemica crisi economica di quei tempi e per l'avvio del primo conflitto mondiale, tali interventi non furono però tutti attuati e la città di Napoli si ritrovò, agli inizi del secolo, con estese zone sventrate da cantieri mai portati a termine in un contesto fortemente degradato anche per la mancata manutenzione delle strade e degli edifici esistenti [De Seta 1998]. Per sopperire a questo stato di completo degrado fu istituito, nell'agosto del 1925, l'Alto Commissariato per la Città e la Provincia di Napoli, con cui prese avvio una radicale trasformazione della città partenopea. Questo nuovo organismo mirava a proseguire il programma del Risanamento ottocentesco con progetti di alta qualità architettonica. Sono questi gli anni in cui la città si caratterizza per la realizzazione di importanti opere che, in chiave moderna, ripercorrevano gli stili del passato. Tra gli artefici dei più importanti lavori, nonché progettisti di numerose opere, si ricordano gli architetti Marcello Canino, Giulio Ulisse Arata, Luigi Cosenza, Carlo Cocchia e Adolfo Avena [Castagnaro 1998]. 
Fig. 2. Casa Piscitelli, 1938 Disegno originale di Ferdinando Chiaromonte. Prospettiva, disegno a matita su carta. Archivio Chiaromonte.

\section{II caso studio}

È in questo contesto storico che s'inserisce il caso studio. II progetto di una residenza privata borghese commissionata già nel 1938, ma che sarà realizzata solo nel 1950 [I], per un lotto che si collocava lungo un nuovo asse stradale che si stava costruendo in quegli anni, l'attuale via Michelangelo Schipa, prolungamento di via Crispi. In dodici anni, attraversati anche dal secondo conflitto mondiale, il progetto sarà interpretato da tre differenti architetti, dapprima dai più noti Chiaromonte e de Luca, per essere poi realizzato per mano di Luigi Mustica, architetto e costruttore che seppur particolarmente prolifico, non raggiunse mai la notorietà dei primi.

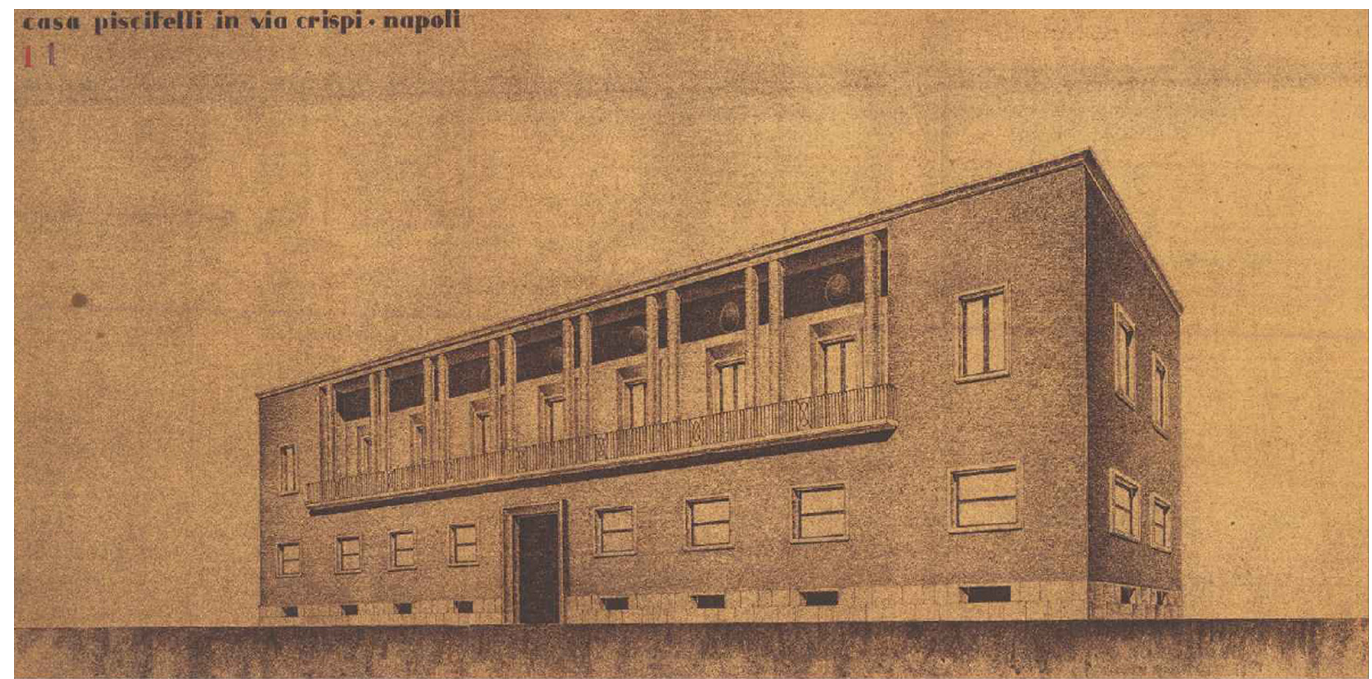

È grazie ai disegni d'archivio dei progetti non realizzati che è stato possibile indagare quella dimensione altra definita dal patrimonio architettonico che avrebbe potuto essere e che mai è stato. Attraverso i disegni originali è "possibile effettuare una 'lettura grafica' approfondita dell'organismo architettonico, per meglio comprendere il concetto di luogo, di funzione, di spazialità, di realizzabilità, in un'unica parola di architettura, intesa come costruzione fruibile dall'uomo, che rispetti i vincoli estetici, funzionali e costruttivi"' [Mezzetti 2008, p. 8]. I disegni evidenziano specificazioni linguistiche che consentono di porre in relazione gli elaborati con i relativi autori, non solo nelle soluzioni proposte, ma anche nell'approccio stesso alla rappresentazione e nelle modalità di documentazione del progetto.

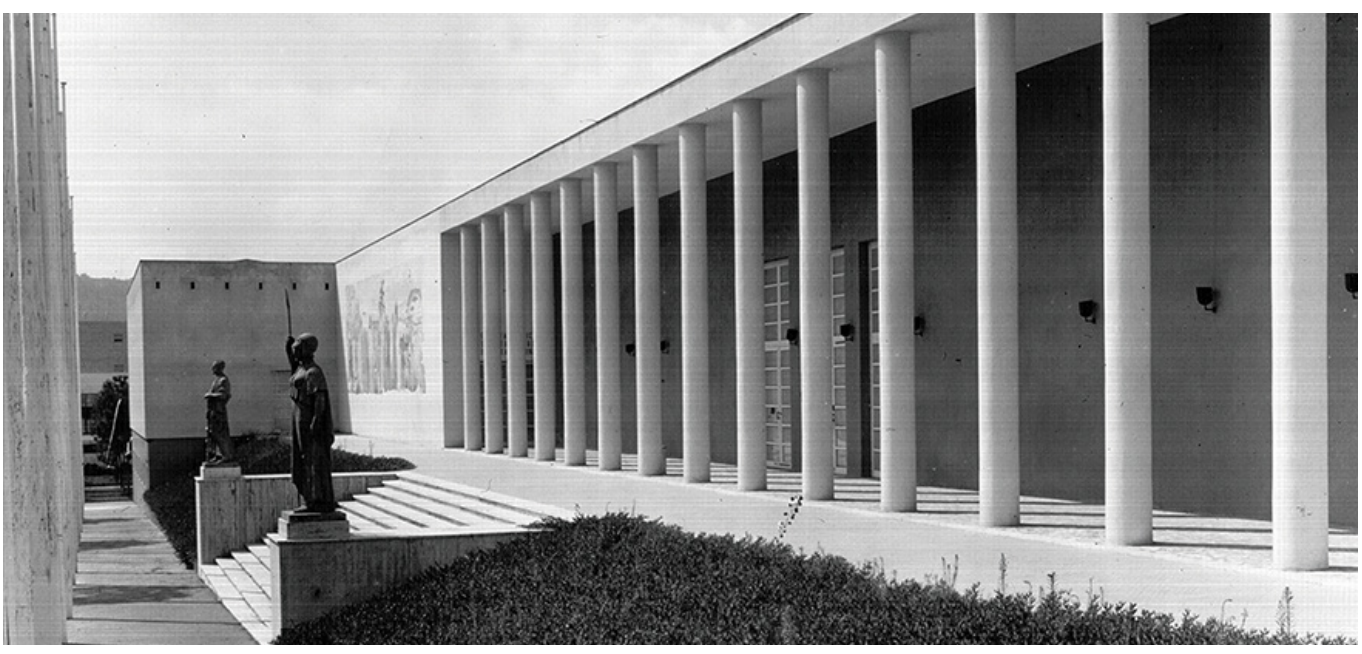


Partendo dall'analisi segnica della documentazione originale, e attraverso la lettura dell'assetto formale e iconologico, sono state elaborate figurazioni e modelli digitali in grado di esplicitare le analisi volumetriche, spaziali e distributive, specifiche dell'analisi grafica [Mezzetti 2008, p. 7].

\section{La prima idea progettuale}

Il primo progetto fu realizzato nel 1938 da Ferdinando Chiaromonte su incarico del Gr. Uff. Attilio Piscitelli [Castagnaro, di Luggo 2008].

La documentazione originale è conservata presso l'Archivio della famiglia Chiaromonte e si compone di sette elaborati grafici tutti realizzati a china su carta lucida fatta eccezione per quella che è la figurazione più suggestiva della raccolta: una prospettiva accidentale dell'edificio realizzata a matita su carta.

Una prospettiva in cui il piano d'orizzonte e il piano geometrale coincidono. Traccia e fuga del geometrale - retta fondamentale $f$ e d'orizzonte $o$ - corrispondono alla retta di sostegno dell'immagine prospettica, sottolineata dall'alta fascia scura disegnata dal tratto pastoso della matita. Chiaromonte, abile e raffinato disegnatore, costruisce un'immagine 'improbabile', ovvero che non può evocare una possibile visione realistica dell'edificio in quanto pone il punto di vista sul piano orizzontale di riferimento [2]. Tale scelta, in deroga alla più comune
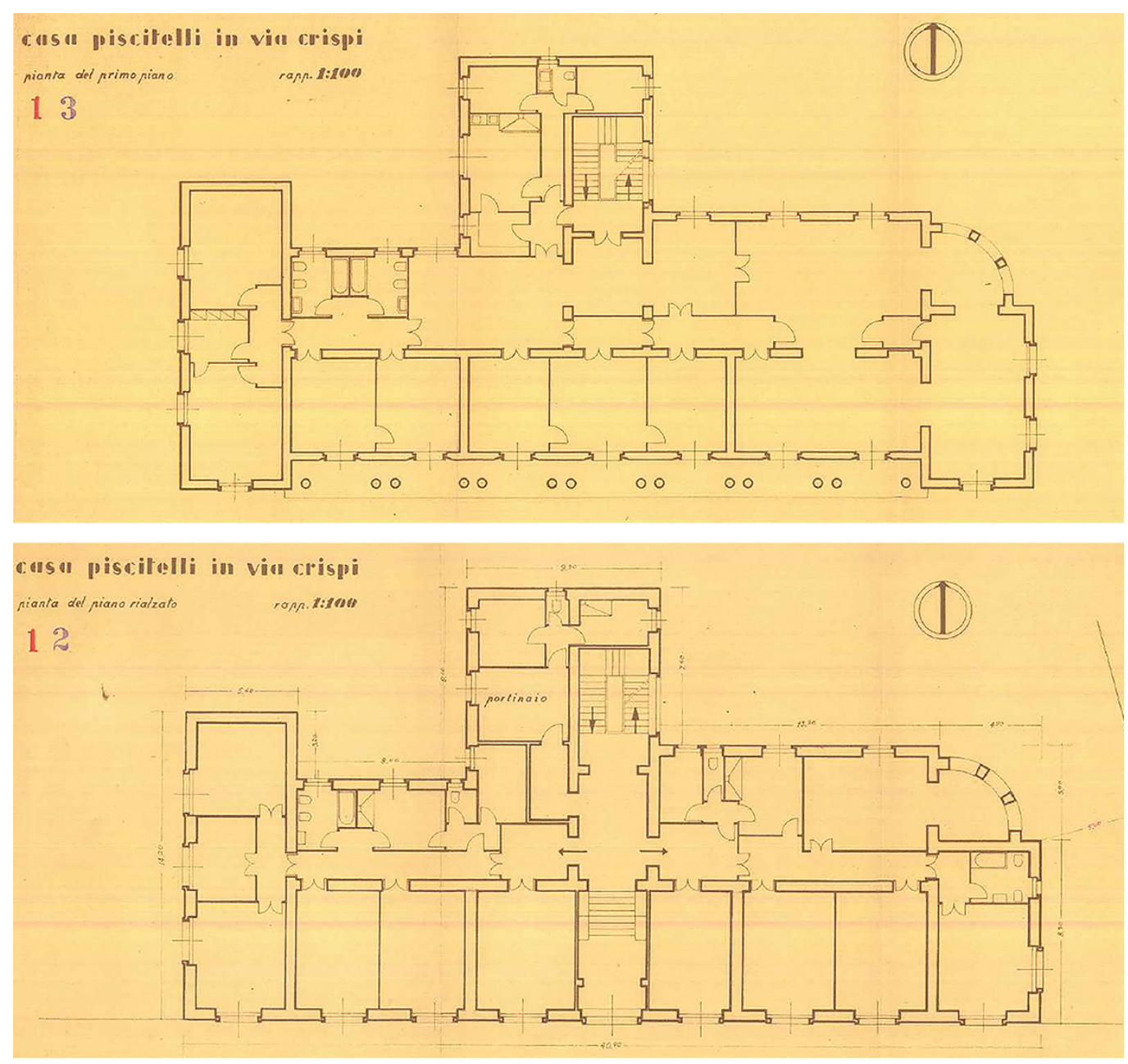
pratica di costruire immagini che possano restituire percezioni verosimili dell'edificio, punta sull'efficacia comunicativa dell'immagine. Qui la sobria architettura, frutto di rielaborazioni di forme classiche sapientemente reinterpretate in un nuovo linguaggio, si manifesta attraverso forme stereometriche pure. L'immagine è quella di un monumentale parallelepipedo in cui il prospetto principale, articolato su due piani fuori terra [3] e un piano seminterrato, quintuplica la lunghezza del fronte laterale. Quest'ultimo, però, è solo parzialmente visibile. Infatti, l'articolazione leggibile nei due elaborati di pianta, fatta di corpi sfalsati nonché di un volume cilindrico di raccordo tra due fronti, denuncia una maggiore complessità compositiva che qualifica l'edificio nella parte posteriore.
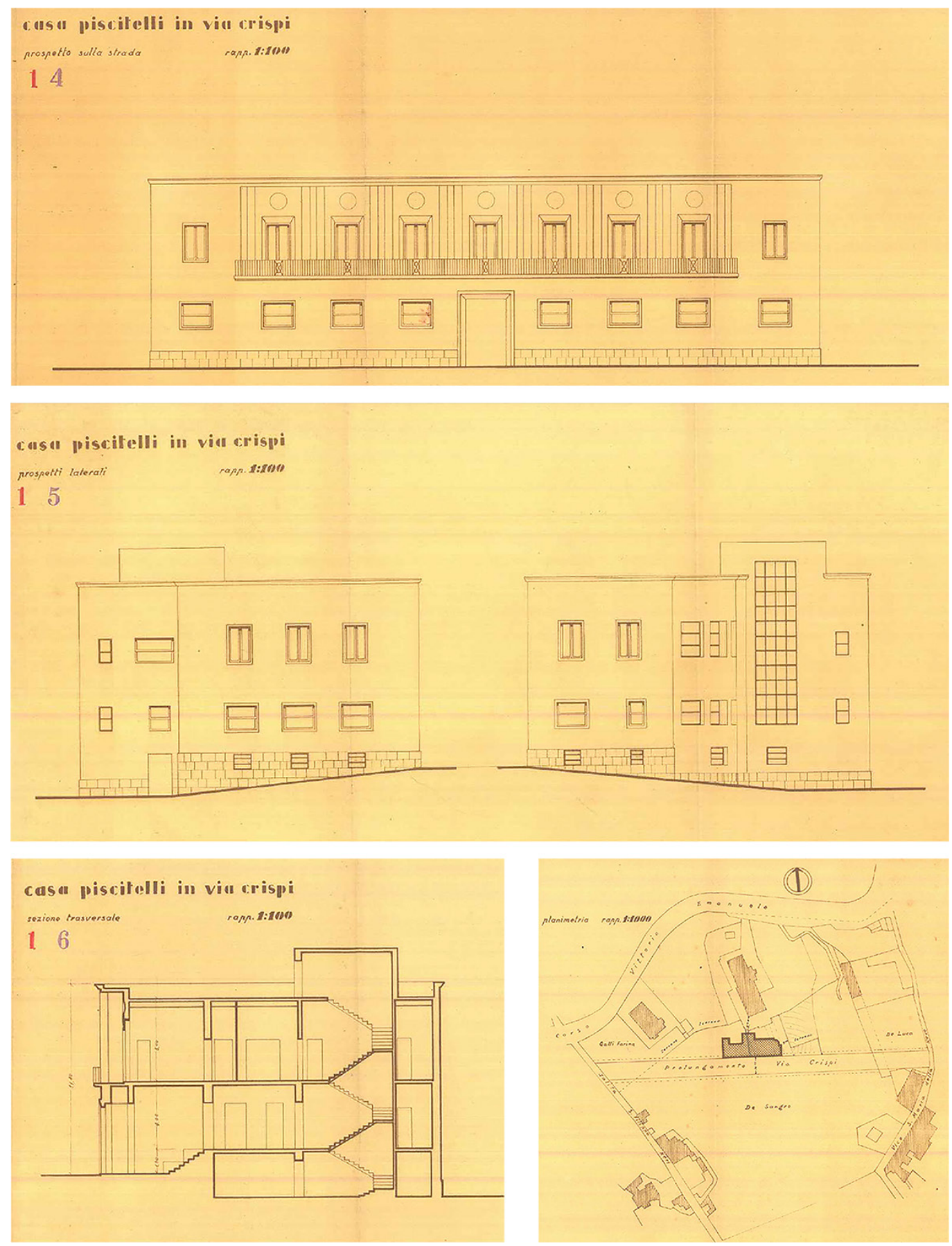
Rigore compositivo e simmetria assiale caratterizzano il disegno del prospetto principale, simmetria che non si riflette nell'articolazione planimetrica. II ritmo in facciata è descritto dagli assi delle bucature, incolonnate ma di forma differente per i diversi livelli. Le portefinestre del primo piano sono inoltre arretrate rispetto al piano della facciata ed inquadrate da una grande loggia ritmata da colonne binate. Ė questo l'elemento predominante della figurazione che conferisce profondità alla composizione interpretata dagli efficaci effetti chiaroscurali dell'immagine prospettica. In essa è possibile apprezzare anche il disegno delle cornici, che risaltano il grande portale, nonché la strombatura delle bucature del primo livello su cui campeggiano scudi circolari leggermente rientranti nella muratura.

La documentazione grafica d'archivio riferita ad elaborazioni bidimensionali, tutti in scala I: I00, si compone, oltre che per le piante dei due livelli, di una sezione trasversale realizzata in mezzeria che intercetta l'ingresso principale e il corpo scala posto sul retro dell'edificio; di una tavola con i due prospetti laterali, dai quali si evincono le diverse soluzioni per le bucature [4], oltre a leggere il dislivello tra il piano stradale e il lotto nel suo sviluppo verso nord. Completa la raccolta una planimetria in scala I: I000 in cui l'edificio si relaziona ad un contesto urbano ancora in fase di definizione.

Il tema della loggia, elemento compositivo che come vedremo ritornerà, anche se con modalità differenti, in tutte e tre le proposte progettuali di casa Piscitelli, rappresenta un tema caro per Chiaromonte. In molti hanno sottolineato le affinità tra la soluzione del progetto della sopra descritta residenza e il Padiglione della Sanità, Razza e Cultura che il nostro realizzerà nel 1940 per la Mostra d'Oltremare. La loggia è qui interpretata ad un'altra scala, ma con uguale e sapiente efficacia il progetto rappresenta un compromesso tra la reinterpretazione delle forme classiche e un nuovo linguaggio che si proietta verso una nuova modernità.

\section{La proposta degli anni quaranta}

Tre anni più tardi, nel 194I, il progetto venne affidato all'architetto Giulio de Luca. Anche in questo caso i disegni originali, custoditi presso l'Archivio de Luca, hanno consentito di leggere opportunamente il progetto, non solo attraverso le diverse convenzioni grafiche adottate $\mathrm{ma}$ anche in considerazione delle specifiche tecniche di rappresentazione. L'idea di base su cui si fonda il progetto è quella di prevedere un edificio che con la sua conformazione planimetrica si inserisca nella forma allungata e irregolare del lotto, sottolineando in tal modo il legame che necessariamente deve sussistere tra il costruito e l'ambiente circostante. Secondo i canoni razionalisti dell'epoca, che privilegiavano la semplificazione delle forme e i volumi puri, de Luca progetta un edificio lineare ed essenziale formato da due bassi volumi tra di loro sfalsati articolati su due livelli. II primo, in posizione avanzata e di più ampia dimensione, caratterizza con il contiguo portico architravato il prospetto che fronteggia la strada e accoglie al primo piano l'appartamento del committente, mentre al piano terra uno dei due appartamenti da locare e la casa del custode. II secondo volume, arretrato, si compone di un semplice corpo allungato ritmato da una sequenza di bucature che illuminano al piano terra il secondo appartamento da affittare e al primo piano la zona notte dell'appartamento padronale [Bertoli 20I3]. L'impronta razionalista, leggibile nella chiarezza compositiva d'insieme, è riscontrabile nei prospetti intonacati privi di ogni decorazione. Unica concessione è rappresentata dal rivestimento in lastre di travertino impiegato per l'intero piano terra e per caratterizzare la loggia, definita come corpo aggettante posto al primo piano del volume principale. Questa, aperta verso il golfo di Napoli, è linguisticamente declinata in una successione di pilastrini, in luogo delle colonne binate immaginate da Chiaromonte. Alla loggia si accede tramite grandi vetrate strette tra pilastri. Gli elaborati grafici originali, la pianta del piano terra, i tre prospetti e le due sezioni, si caratterizzano per l'uso delle ombre che aiutano a leggere i rapporti tra le volumetrie. Negli elaborati si rileva inoltre l'attenzione al disegno del verde e, limitatamente alla prospettiva accidentale, anche l'inserimento di diverse sagome umane che tendono ad esaltare, ma anche ad accentuare, la scala e la dimensione architettonica immaginata. 
Fig. 6. Progetto di $\checkmark$ illa Piscitelli, Giulio de Luca 194I. Pianta del piano terra, prospetto anteriore prospetti laterali e sezioni trasversali. Elaborati realizzati in scala 1:100. Archivio privato de Luca.
Fig. 7.Villa Piscitelli, 1941. Disegno originale di Giulio de Luca. Prospettiva, disegno a china. Archivio privato de Luca.

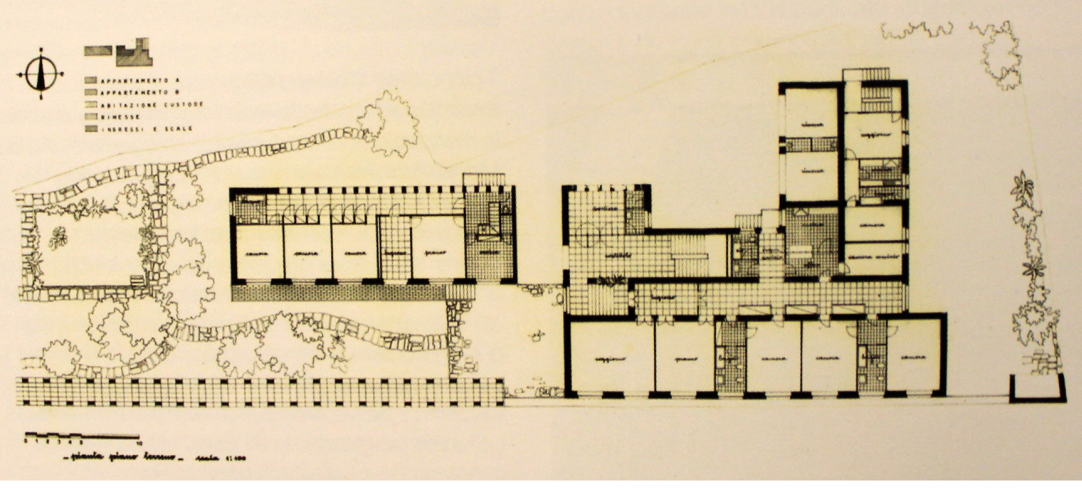

施 IIIUL:
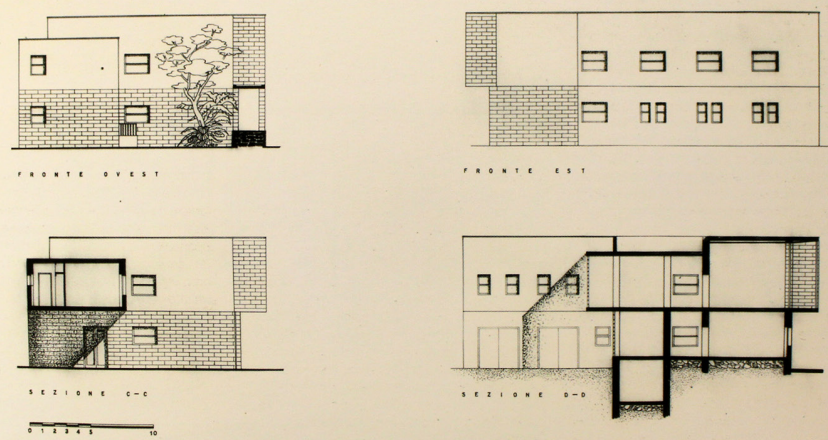

VILLA PISCITELLI VIA CRISPI

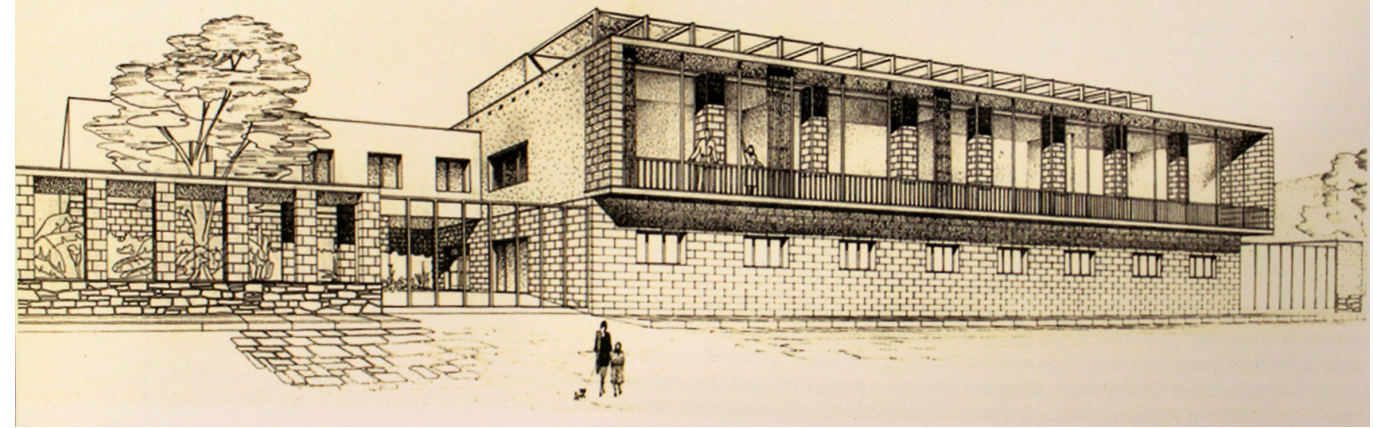


Fig. 8. Processamento ed elaborazione dei dati in Metashape (il rilievo fotogrammetrico e il processamento dei dati sono stati eseguiti da Sabrina Acquaviva e Marika Falcone)
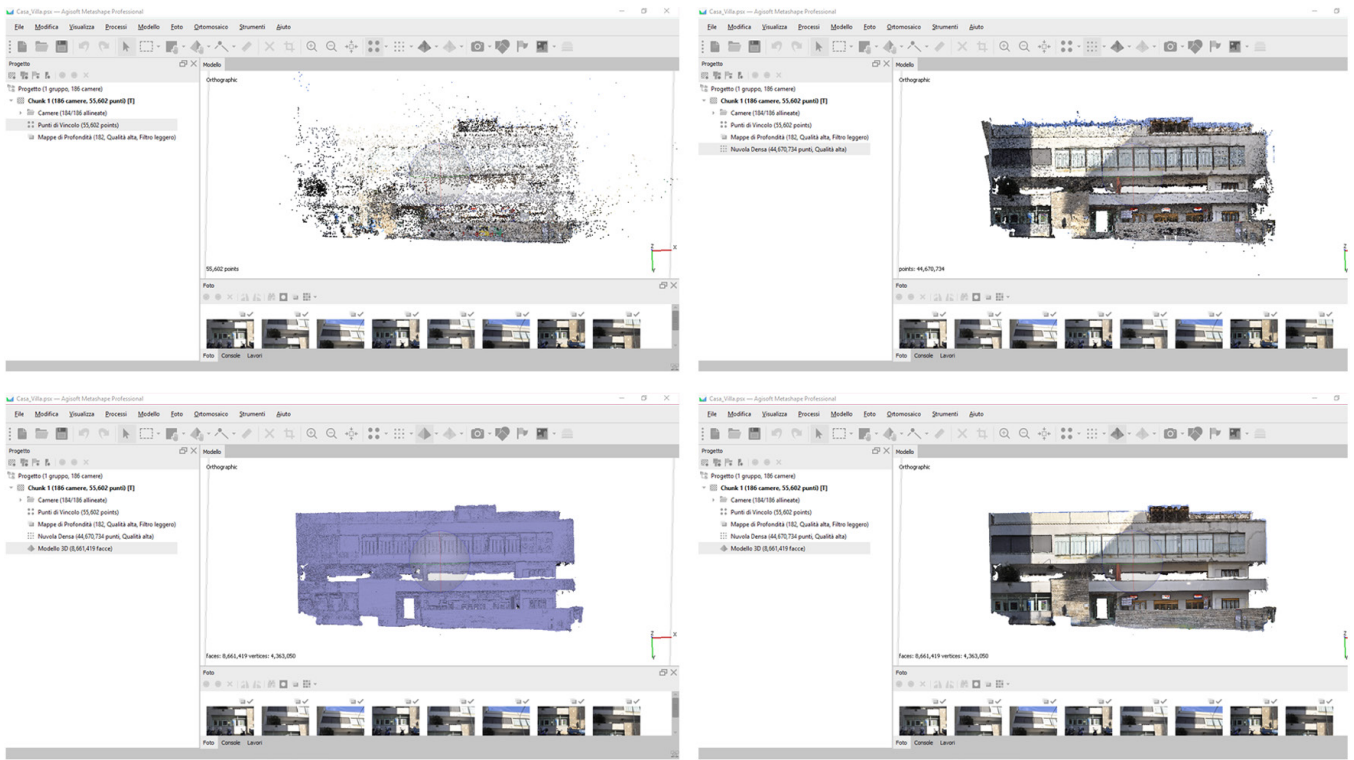

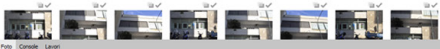

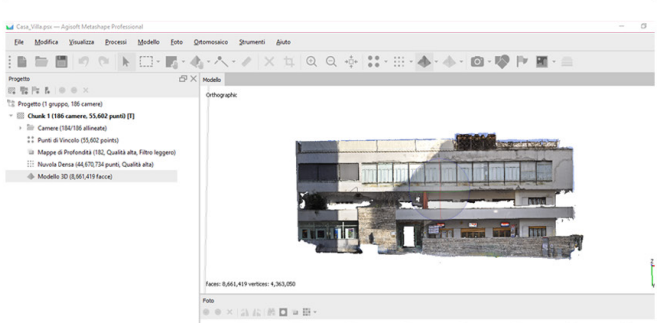

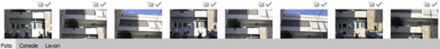

\section{La conoscenza dell'architettura realizzata}

L'impossibilità di reperire i disegni originali di Luigi Mustica o una documentazione che consentisse di analizzare l'articolazione planimetrica dell'edificio, oltre all'inaccessibilità delle proprietà private, ha condizionato la metodologia di studio che si è dovuta limitare ad indagini conoscitive delle sole configurazioni esterne, privilegiando lo studio del prospetto principale. Procedure di rilievo integrate, rilievo diretto e rilievo fotogrammetrico terrestre, hanno permesso l'elaborazione delle figurazioni utili ad esplicitare le analisi e le letture condotte.

Nel rilievo fotogrammetrico la registrazione delle informazioni metriche e colorimetriche della facciata principale è avvenuta con una fotocamera Nikon D5000, con la quale si è scelto di eseguire le riprese fotografiche garantendo un overlap del $60 \%$ tra i fotogrammi. In relazione alle limitate possibilità di ripresa [5], si è deciso di settare la lunghezza focale a 24 mm con tecnica di presa sia ad assi paralleli sia ad assi convergenti, recuperando in tal modo

Fig. 9. Casa Piscitelli, restituzione grafica del prospetto principale realizzato su progetto d Lulgi Mustica nel La figurazione, sintesi e interpretazione de caratteri compositivi del progetto è posta in relazione con porzioni di ortofoto elaborata dal rilievo fotogrammetrico (elaborazione grafica di Sabrina Acquaviva e Marika Falcone).

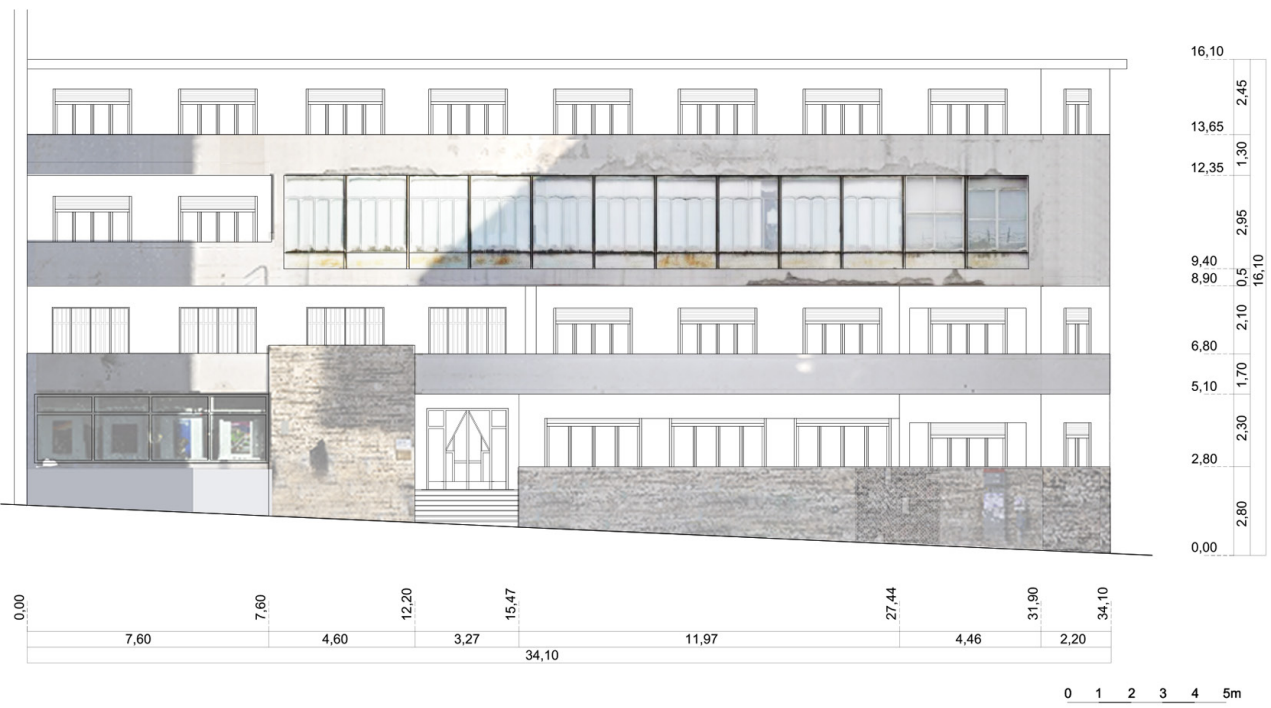


informazioni spaziali su diversi livelli di profondità. La pianificazione della battuta fotografica ha dovuto tener conto, tra le altre cose, anche delle differenti condizioni di illuminazione del fronte, al fine di evitare zone fortemente in ombra, e favorire il processamento automatico e una più rapida e corretta elaborazione dei dati. I fotogrammi sono stati processati, impostando parametri di alta qualità, con il software Structure from motion-Metashape dell'Agisoft. Nella prima fase di elaborazione sono stati allineati i vari fotogrammi ottenendo, attraverso il riconoscimento dei punti omologhi, la nuvola di punti sparsa. In seguito si è proceduto ad un infittimento dei punti della nuvola (dense cloud) e all'elaborazione del modello tridimensionale poligonale (mesh), su cui sono state poi proiettate le foto per la creazione del modello texturizzato. Le ortofoto, elaborate dalla nuvola di punti tridimensionale, sono state impiegate per la figurazione degli elaborati grafici frutto di discretizzazione dei dati ed interpretazione degli stessi [Remondino 20I I].

Il progetto di Mustica si articola su quattro livelli fuori terra, ognuno destinato ad accogliere tre appartamenti, oltre ad un piano seminterrato adibito a garage. Se da un lato l'articolazione volumetrica d'insieme si discosta dalle precedenti soluzioni, dall'altro si conferma la volontà di caratterizzare il fronte con una soluzione di forte impatto visivo. Qui il tema della loggia, di lecorbusierana memoria, qualifica sia il prospetto principale che quello laterale. Un'altra soluzione per la quale è possibile tracciare delle letture parallele con i progetti non realizzati, è rappresentata dal disegno del rivestimento in pietra incerta del basamento. Trame e soluzioni differenti disegnano le figurazioni dei tre basamenti. Chiaromonte immagina, sul fronte principale, una bassa zoccolatura in pietra la cui continuità è interrotta dalle bocca di lupo del piano seminterrato. Inoltre la sua altezza raddoppia sui fronti posteriori a causa del salto di quota imposto dal sito.

Se in de Luca il basamento dell'intero edificio è uniformemente scandito dal disegno regolare delle lastre in travertino, Mustica sceglie di impiegare solo parzialmente il rivestimento in pietra per caratterizzare due differenti parti: nella sua interpretazione della zoccolatura, che interessa solo limitatamente il basamento, e nel volume che realizza quale connessione tra il basamento e il livello superiore.
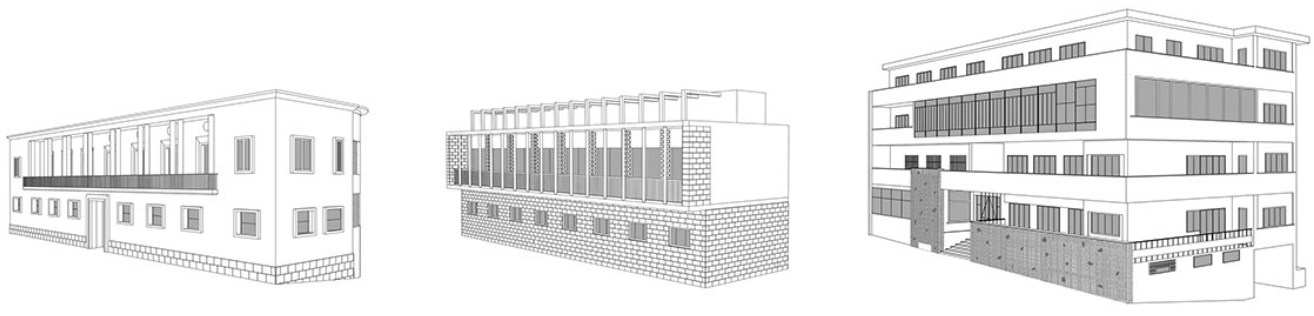

Fig. 10. I tre progetti
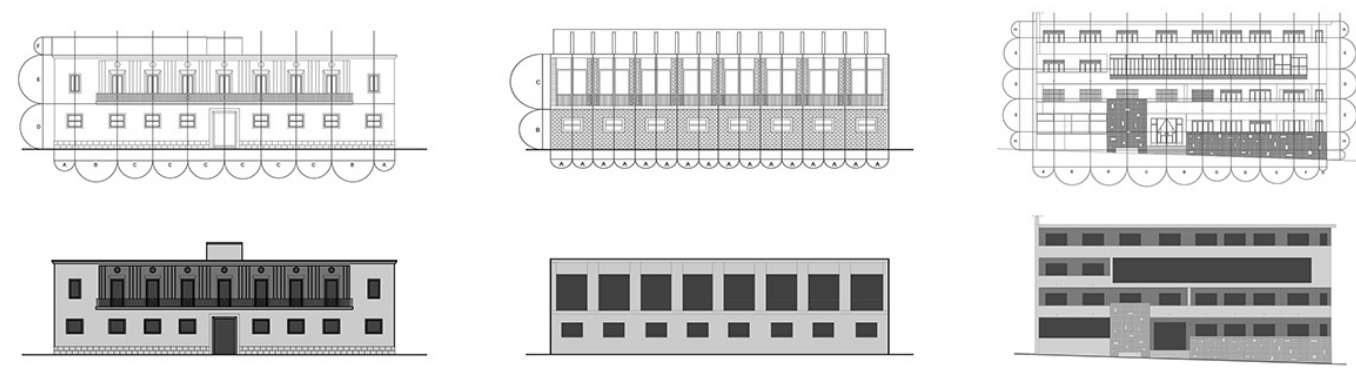


\section{Conclusioni}

Il tema del confronto tra le diverse interpretazioni di uno stesso progetto suggerisce di individuare e/o verificare eventuali relazioni tra le idee, di tessere e annodare possibili rapporti, di riconoscere diversità e analogie. Questi processi conoscitivi, quando riferiti ad architetture non più esistenti o mai realizzate, si possono avverare grazie al disegno, alla documentazione iconografica esistente, per essere poi raccontati ed esplicitati anche attraverso nuove figurazioni.

Quello proposto è un racconto in tre tappe, di tre differenti figurazioni, con il quale rivelare il carattere compositivo, linguistico e formale dei tre differenti progettisti.

Lo sguardo è stato qui rivolto ad un'architettura, casa Piscitelli, il cui studio ha aperto e proiettato verso dimensioni altre che non si esauriscono nella sola analisi del progetto realizzato. Rintracciare le fonti e indagarne la storia, suggerisce di riannodare e rammagliare tre distinti momenti. È inevitabile individuare i legami che l'architettura tesse con il tessuto urbano in cui insiste, ma è ancor più stimolante indagare e investigare quelle relazioni non visibili, quelle possibili connessioni che solo la lettura attenta delle fonti, della documentazione originale, possono rivelare.
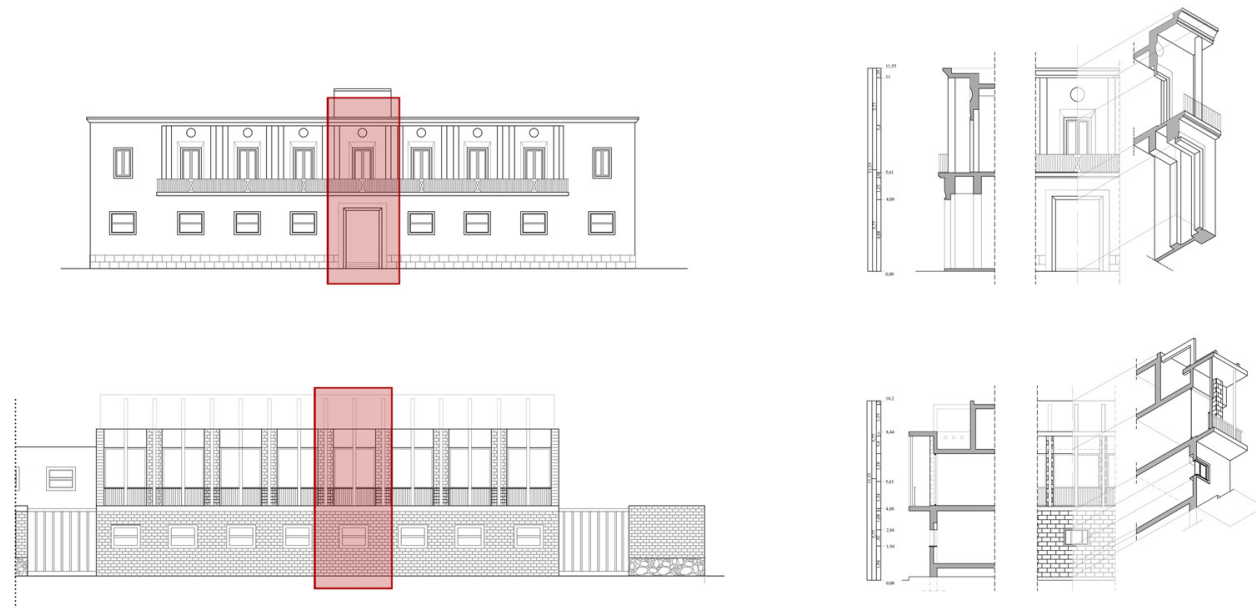

Fig. I I. Analisi compositiva e comparativa del fronte principale (i disegni sono stati elaborati da Giuseppe Volanti nell'ambito della sua tesi di laurea in Scienze dell'Architettura, relatore prof. arch. Antonella di Luggo, correlatore arch. Daniela Palomba).
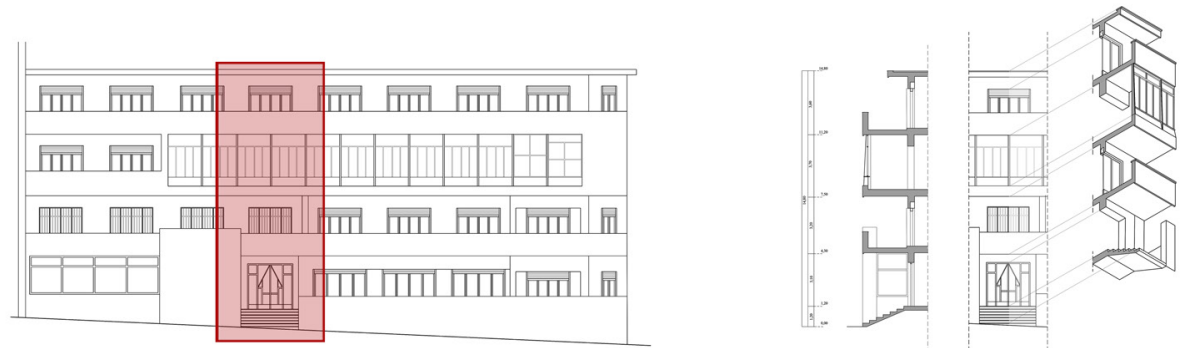

Note

[I] Come specificato dalla di Luggo diversi furono gli impedimenti sia di carattere giuridico che amministrativo che causarono il rinvio della costruzione della residenza Piscitelli al 1950 su progetto dell'arch. Luigi Mustica. [Castagnaro, di Luggo 2008].

[2] In questa figurazione all'osservatore è assegnata una quota nulla. È doveroso sottolineare che questa immagine prospettica è compatibile anche con una proiezione in cui l'oggetto è posto sul piano d'orizzonte, ovvero sul piano parallelo al geometrale condotto per l'osservatore.

[3] II progetto prevedeva due appartamenti al piano rialzato ed uno di più ampia metratura al primo piano.

[4] II corpo scala è illuminato da una grande finestra che attraversa in altezza l'intero edificio.

[5] Le caratteristiche urbanistiche del sito molto si discostano dalle condizioni in cui si trovarono a ragionare i nostri, anche se già note erano le programmazioni di edificazione dell'area. 


\section{Riferimenti bibliografici}

Belfiore Pasquale, Gravagnuolo Benedetto (1994). Napoli. Architettura e Urbanistica del Novecento. Napoli: Laterza Roma-Bari. Bertoli Barbara (2013). Giulio de Luca 1912-2004. Opere e Progetti. Napoli: Clean.

Castagnaro Alessandro, di Luggo Antonella (2008). Ferdinando Chiaromonte. Disegni, opere, progetti. Napoli: Officina Edizioni. Castagnaro Alessandro (1998). Architettura del Novecento a Napoli. Napoli: Edizioni Scientifiche Italiane.

De Seta Cesare (1998). L'architettura a Napoli tra le due guerre. Napoli: Electra Napoli.

De Rubertis Roberto (1994). Il disegno dell'architettura. Roma: Carocci.

Mezzetti Carlo (2008). II disegno della palazzina romana. Roma: Edizioni Kappa.

Remondino Fabio (20 I I). Heritage Recording and 3D Modeling with Photogrammetry and 3D Scanning. In Remote sensing, 3(6), pp I 104-।|38.

Remondino Fabio et al. (2017). A critical review of automated photogrammetry processing of large dataset. In Int. Arch. Photogramm in Remote Sens. Spatial Inf. Sci., XLII-2M5: 59I-599.

Ugo Vittorio (2008). Sulla critica della rappresentazione nell'architettura. Milano: Maggioli Editore.

Autori

Daniela Palomba, Università degli Studi di Napoli Federico II, daniela.palomba@unina.it

Sabrina Acquaviva, Università degli Studi di Napoli Federico II, s.acquaviva87@libero.it

Marika Falcone, Università degli Studi di Napoli Federico II, marique93@gmail.com

Per citare questo capitolo: Palomba Daniela, Acquaviva Sabrina, Falcone Marika (2020). Connessioni temporali: lettura critica di un progetto in tre tempi/Temporal Connections: critical reading of a project in three times. In Arena A., Arena M., Brandolino R.G., Colistra D., Ginex G., Mediati D., Nucifora S., Raffa P. (a cura di). Connettere. Un disegno per annodare e tessere. Atti del $42^{\circ}$ Convegno Internazionale dei Docenti delle Discipline della Rappresentazione/Connecting. Drawing for weaving relationships. Proceedings of the 42th International Conference of Representation Disciplines Teachers. Milano: FrancoAngeli, pp. 2493-25।4. 


\title{
Temporal Connections: Critical Reading of a Project in Three Times
}

\author{
Daniela Palomba \\ Sabrina Acquaviva \\ Marika Falcone
}

Abstract

The essay presents a study on Casa Piscitelli, a residential bourgeois building built in Naples in the Chiaia district, in the middle of the last century. For its design several architects were involved among the most illustrious protagonists of the Neapolitan panorama. Three projects that describe the taste, the experimentation and the compositional characters that qualified the architectural language of those years. Three architects who interpreted, at different times, the requests of the same client: Chiaromonte, de Luca and Mustica. The study was conducted by reading the archive drawings of the projects not carried out, those projects "examples of things ... that will never be" are investigated and compared with the configuration of the work realized. The theme of the comparison between the different interpretations of the same project suggests to identify and/or verify possible relations between ideas, to weave and knot possible reports, to recognize diversity and similarities. These cognitive processes, when referred to architectures no longer existing or ever realized, can be realized thanks to the drawing, the existing iconographic documentation, and then told and explained also through new figurations.

Keywords

Villa Piscitelli, photogrammetric survey, representation, comparison, configuration.
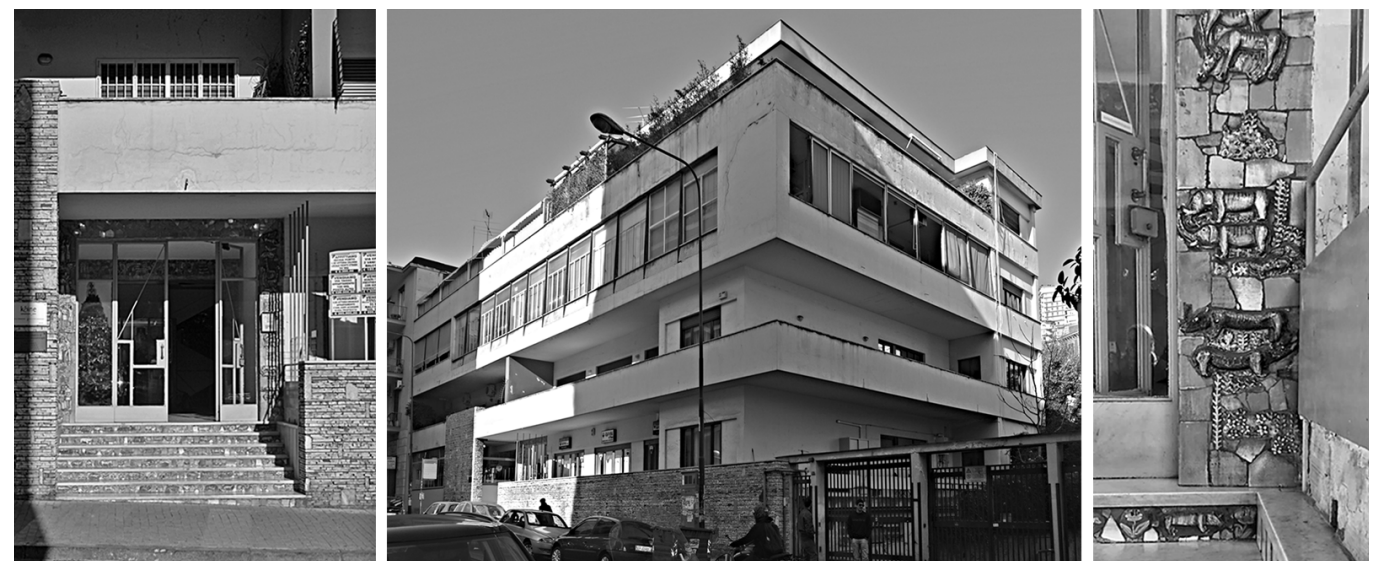


\section{Introduction}

Drawing in its different connotations forms and makes explicit the thought and the image of architecture, connotating itself as a language through which the real becomes manifest in its physicality and in the history of its becoming. In the narration of architecture, drawing is in fact the visual support of a story that takes place over time, being able to document not only the transformations, but also the potential existences that have manifested themselves over time, reconnecting the different figurations and allowing to place on a single plane of the comparison languages and expressive specificities. In this context of reflections it seemed interesting to examine a case study whose figurations have multiplied over time and whose representation is offered as a theoretical/graphic device capable of creating new connections, explaining similarities and differences that are evident in comparison. It's a building located in one of the areas of expansion that affected the city of Naples in the first half of the 20th century and was the occasion of design experimentation by some architects protagonists of the Neapolitan architectural scene of those years.

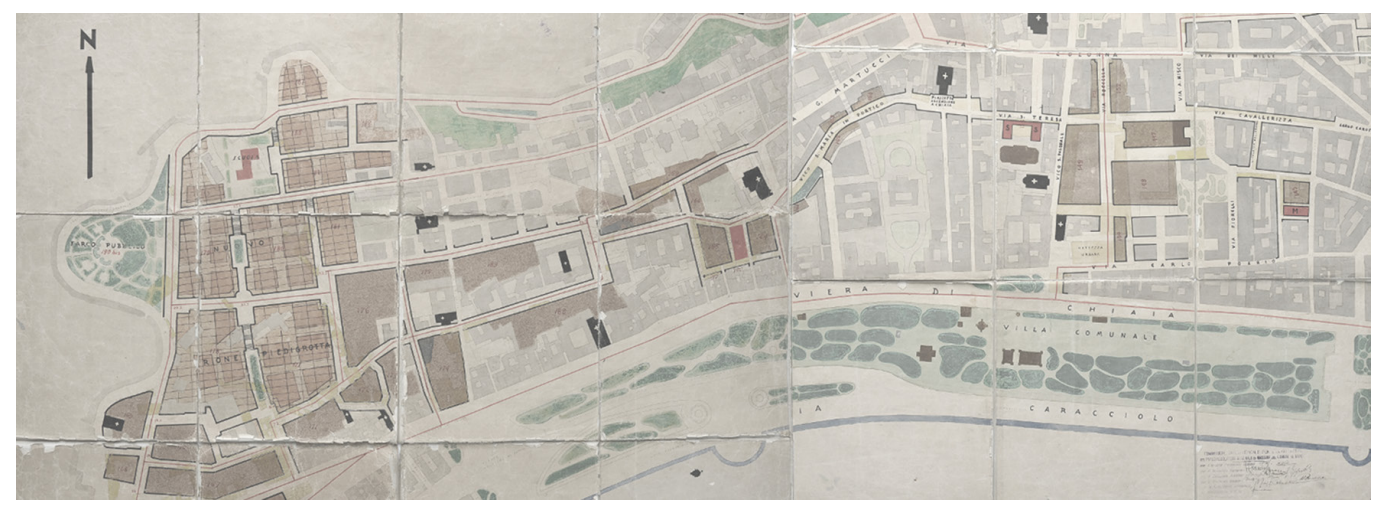

\section{The Neapolitan architecture between the two world conflicts}

On the eve of the Second World War, after a twenty-year fascist regime and decades later than other Italian cities, Naples lived a new fervour with the construction of new buildings and entire residential districts. This important building activity had begun in 1885 with the law for the Rehabilitation in which the interventions aimed at the reclamation of the building, the realization of the collective services and the reorganization of public roads were planned. As is well known, due to the endemic economic crisis of those years and the beginning of the First World War, such interventions were never implemented and the city of Naples, at the beginning of the century, appeared to be heavily degraded due to construction sites never completed and lack of maintenance of streets and residential buildings [De Seta 1998].To compensate for this state of complete degradation, the High Commissariat was established in August 1925 with which began a radical transformation of the Neapolitan city.This new organization aimed to continue the program of the nineteenth-century restoration with projects of high architectural quality. These are the years in which the city is characterized by the realization of important works that, in a modern key, retraced the styles of the past. Among the architects of the most important works, we remember Marcello Canino, Giulio Ulisse Arata, Luigi Cosenza, Carlo Cocchia, Adolfo Avena [Castagnaro 1998]. 


\section{The case study}

It's in this historical context that the case study fits. The project of a bourgeois private residence commissioned already in 1938, but that will be realized only in 1950 [ I], for a lot placed along a new road axis that was being built in those years, the present Via Michelangelo Schipa, extension of Via Crispi. In twelve years, also crossed by the Second World War, the project will be interpreted by three different architects, first by the most famous architect Chiaromonte and de Luca, to be realized by Luigi Mustica, architect and builder who although particulary prolific, never reached the fame of the first.

Fig. 2. Villa Piscitelli, 1938 Original drawing by Ferdinando Chiaromonte. Perspective, pencil drawing on paper. Archive of Chiaromonte.

Fig. 3. Mostra d'Oltremare, Pavillion of Health, Race and Culture. Project realized by Ferdinando Chiaromonte, Naples, 1939-1940. Historical photo.

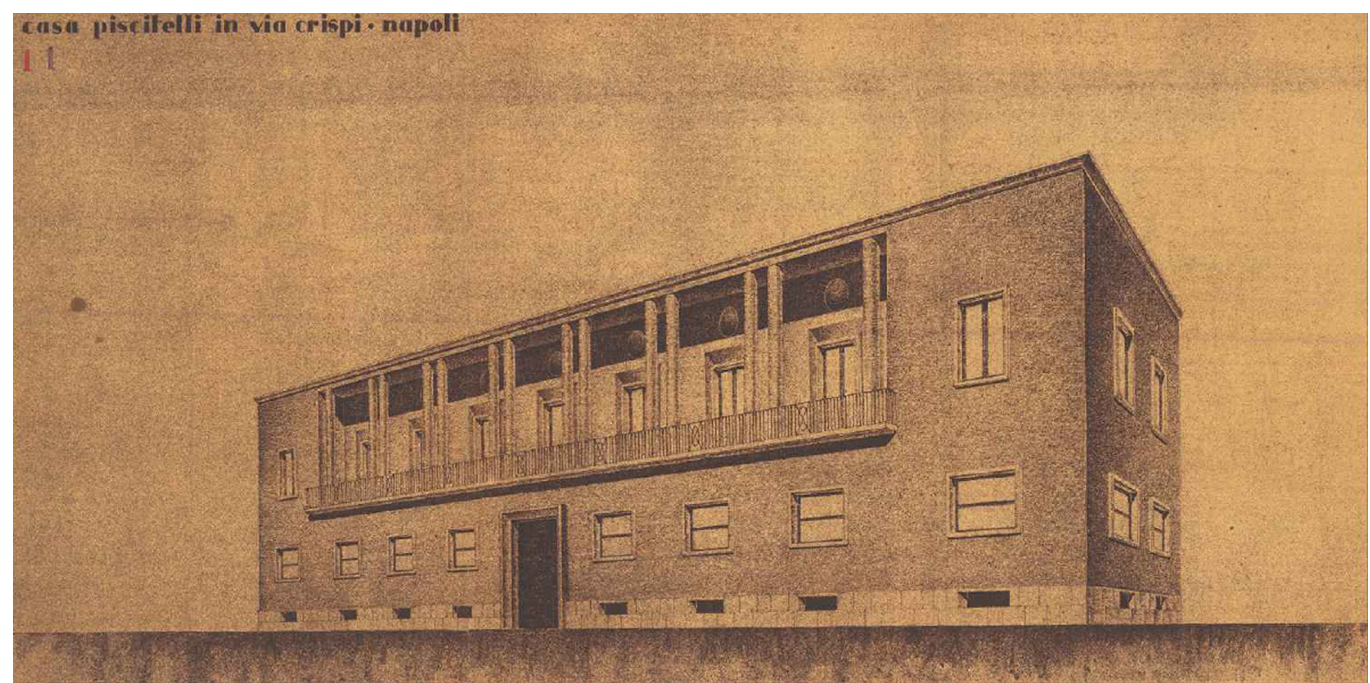

It's thanks to the archive drawings of the unfulfilled projects that it was possible to investigate that other dimension defined by the architectural heritage that could have been and never was. Through the original designs is "possible to carry out a 'graphic reading' in depth of the architectural organism, in order to better understand the concept of place, of function, of spatiality, of realizability, in a single word of architecture, understood as construction usable by the man, which respects aesthetic, functional and constructive constraints" [Mezzetti 2008, p. 8].

The drawings highlight linguistic specifications that allow to relate the elaborates with their authors, not only in the proposed solutions, but also in the approach itself to the representation and in the modalities of documentation of the project.

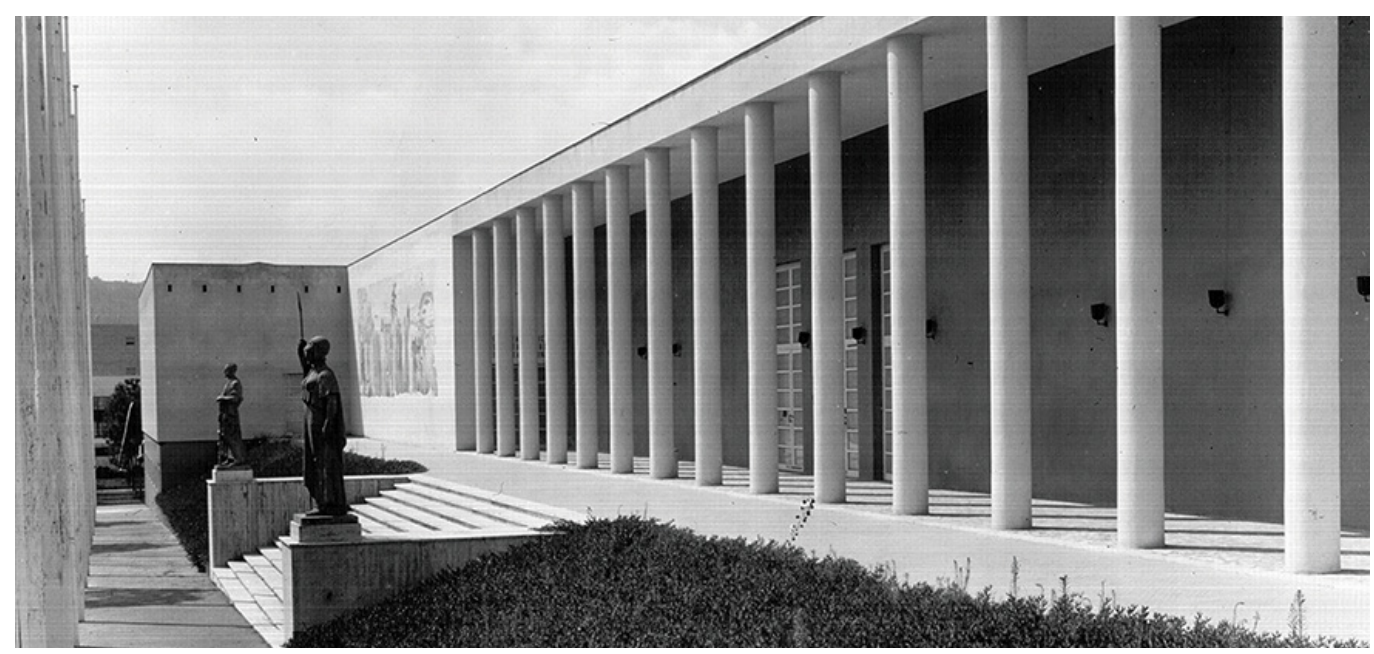


Starting from the sign analysis of the original documentation, and through the reading of the formal and iconological set-up, were elaborated figurations and digital models able to explain the volumetric analyses, spatial and distributive, specific of the graphic analysis [Mezzetti 2008, p. 7].

\section{The first design idea}

The first project was realized in 1938 by Ferdinando Chiaromonte and commissioned by Gr. Uff. Attilio Piscitelli [Castagnaro, di Luggo 2008]. The original documentation is kept at the Archive of Chiaromonte's family and is composed by seven graphic works all made of china on glossy paper except for what is the most suggestive picture of the collection: an accidental perspective of the building realized in pencil on paper.

A perspective in which the horizon plan and the geometry plan coincide. Trace and the line of flight of geometric plan -fundamental line $f$ and horizon line $o-$ correspond to the support line of the image perspective, underlined by the high dark band designed by the pasty pencil. Chiaromonte, skillful and refined designer, builds an improbable image that cannot evoke a possible realistic vision of the building because he puts the point of view on the horizontal reference plane [2]. This choice, in exception to the most common practice of building images that can give back perceptions of the building, focuses on the communicative effectiveness of the image.
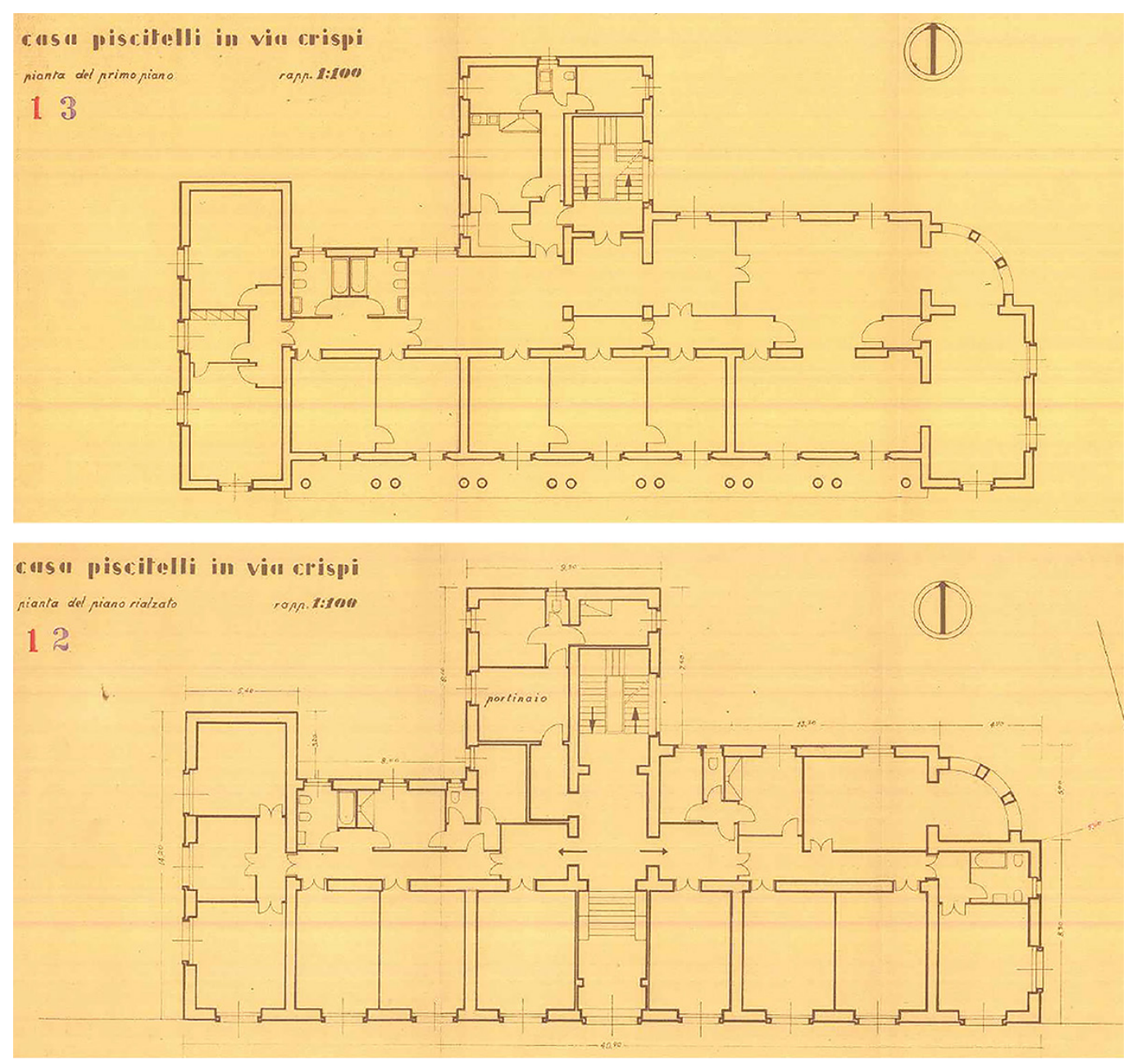
Here the sober architecture, the result of reworking of classic forms skilfully reinterpreted in a new language, manifests itself through pure stereometric forms. The image is that of a monumental parallelepiped in which the main facade, articulated on two floors above ground [3] and a basement, quintuples the length of the lateral front. The latter, however, is only partially visible. In fact, the readable articulation in the two plans, made of staggered bodies as well as a cylindrical volume of connection between two fronts, denotes a greater compositional complexity that qualifies the building in the back. Compositional rigor and
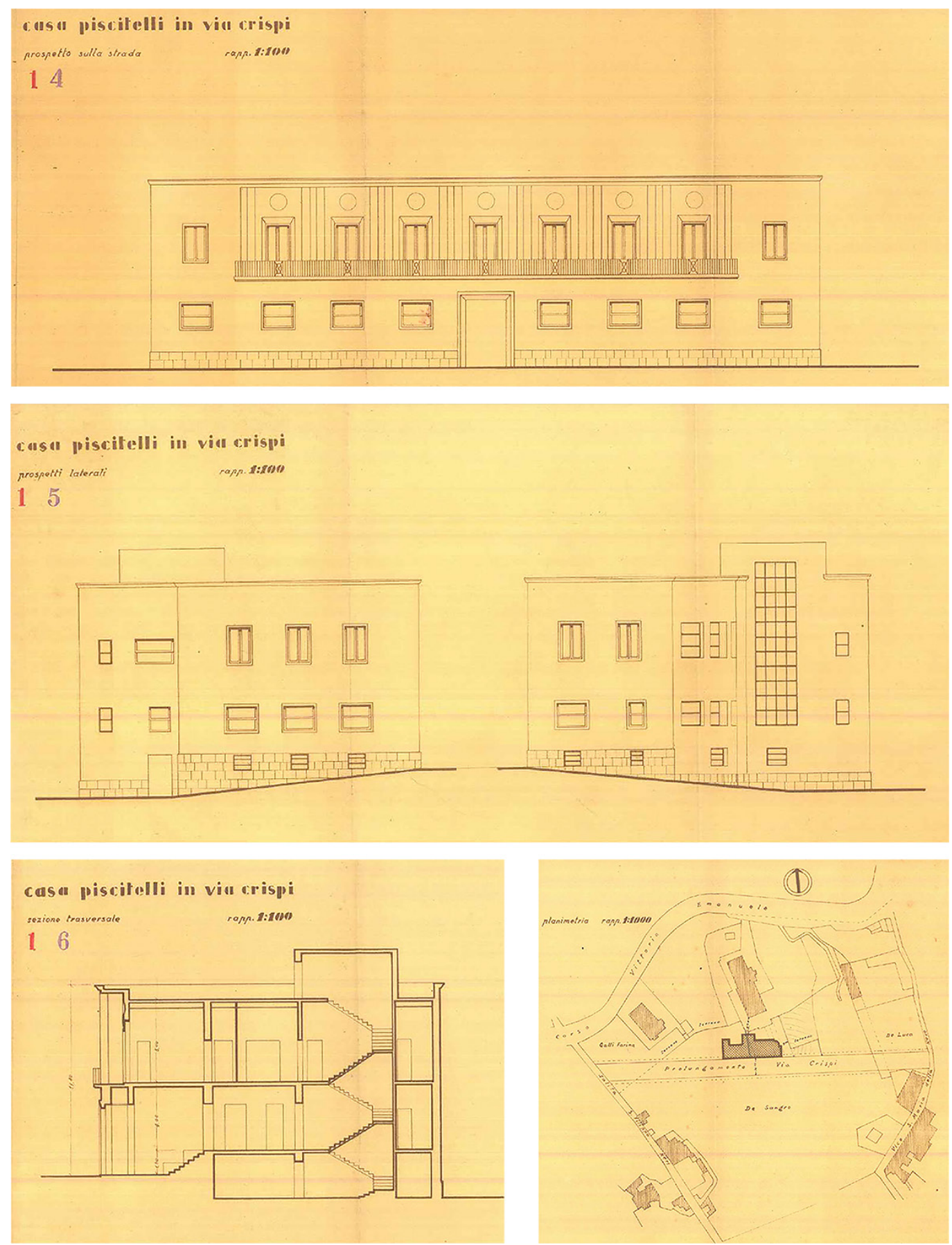
axial symmetry characterize the drawing of the main prospectus, symmetry that isn't reflected in the planimetric articulation. On the façade the rhythm is described by axes of the holes, lined up but with a different shape for the different levels. The French windows on the first floor are also rearward from the floor of the façade and framed by a large loggia with double columns. This is the predominant element of figuration that gives depth to the composition interpreted by the effective chiaroscuro effects of the perspective image. In it's also possible to appreciate the drawing of the frames, which stand out the large portal, as well as the trumpet of the holes of the first level on which stand circular shields slightly recessed in the masonry. The graphical documentation of the archive referring to two-dimensional elaborations, all in scale $1: 100$, is composed, besides that for the plants of the two levels, by a cross section realized in the center that intercepts the main entrance and the staircase body placed on the back of the building; Table with the two lateral facades, from which we deduce the different solutions for the holes [4], besides to read the difference in level between the road plan and the plot in its development to the north. Complete the collection a floor plan in scale 1:1000 in which the building relates to an urban context still being defined. The theme of the loggia, a compositional element that, as we'll see, will return, even if with different modalities, in all three projects of the Casa Piscitelli, is a subject of great interest to the architect Chiaromonte. Many have emphasized the affinities between the solution of the project of the above mentioned residence and the Pavilion of Health, Race and Culture that our will realize in 1940 inside the Mostra d'Oltremare. The loggia is here interpreted on another scale, but with equal and wise effectiveness the project represents a compromise between the reinterpretation of classic forms and a new language that is projected towards a new modernity.

\section{The proposal of the 1940s}

Three years later, in 1941, the project was entrusted to the architect Giulio de Luca. Also, in this case the original drawings, kept at the 'Archivio de Luca', have allowed to read the project appropriately, not only through the different graphic conventions adopted but also in view of the technical specifications of representation. The basic idea behind the project is to provide a building that with its planimetric conformation fits into elongated and irregular shape of the site, thus emphasizing the bond that necessarily must exist between the built and the surrounding environment. According to the rationalist canons of the time, which favored the simplification of forms and pure volumes, de Luca designs a linear and essential building formed by two low volumes among them staggered and articulated on two levels. The first is in an advanced position and larger than the second, and its main facade, together with lintel portico, overlooks the street. It holds the client's apartment on the first floor, while at the ground floor one of the two apartments to rent and the guardian's house. The second volume, set-back, is composed by simple body rhythmic and elongated by a sequence of holes that illuminate at the ground floor the second apartment to rent and on the first floor the sleeping area of the apartment master [Bertoli 20/3].

The rationalist influence readable in the clarity compositional of the whole can be found in plastered facade without any decoration. Only concession is represented by the covering in travertine slabs used for the ground floor and for the loggia, defined as projecting body placed on the first floor of the main volume. The loggia, open towards the gulf of Naples, is composed by a succession of pillars, instead of the coupled columns imagined by Chiaromonte. It is accessed through large narrow windows between pillars. The original drawings, the plan of the ground floor, the three facade and the two sections, are characterized by the use of shadows that help to read the relation between volumes. In addition, there is attention to the design of the green and, limited to the accidental perspective, also the addition of different human shapes that tend to exalt the scale and size architectural imagined. 
Fig. 6. Project ofVilla Piscitelli, Giulio de Luca, |941. Ground floor plan, main façade, lateral façades and cross sections in scale 1:100. Archive of de Luca.

Fig. 7.Villa Piscitelli, 1941. Original drawing by Giulio de Luca. Perspective, drawing on paper.Archive of de Luca.

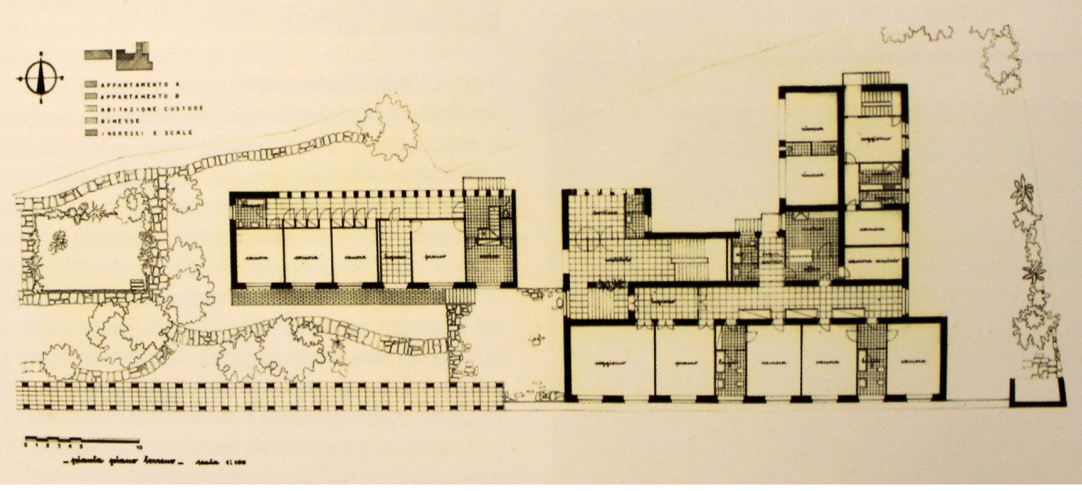

18.

\section{IIIIII)}
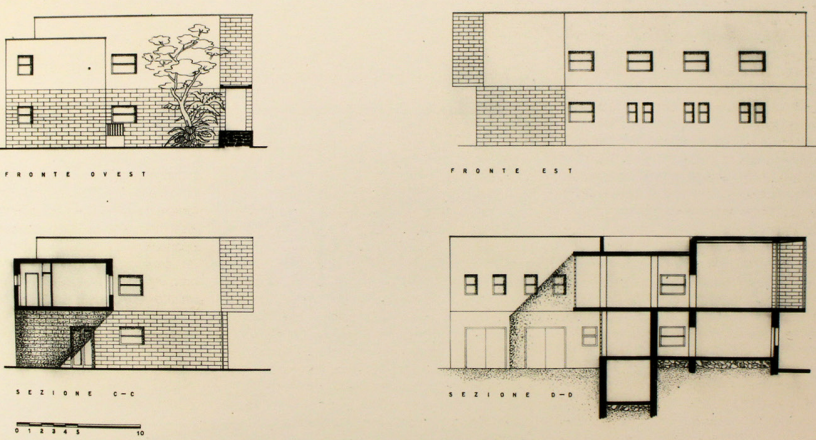

VILLA PISCITELLI VIA CRISPI

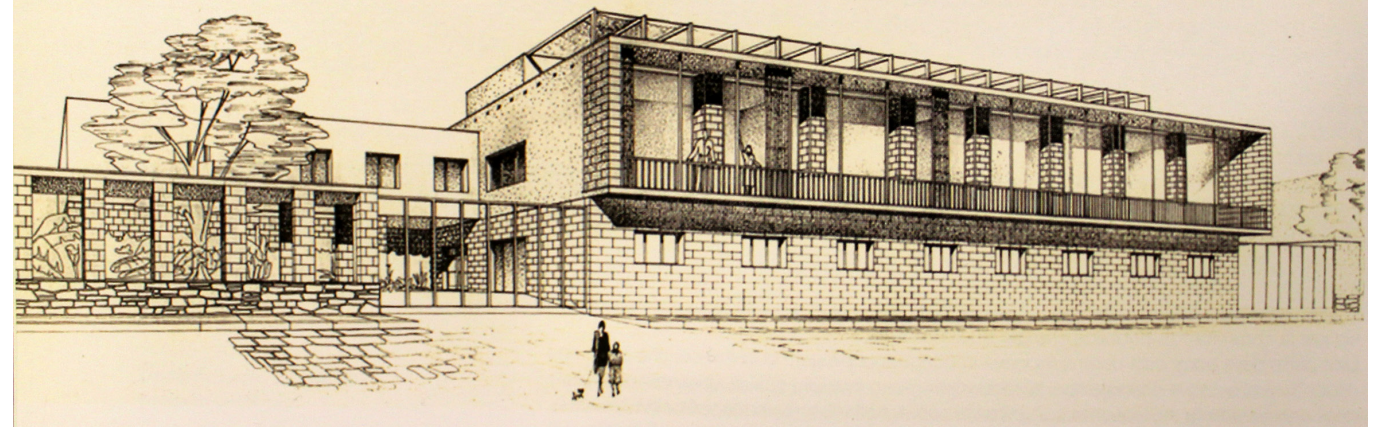


Fig. 8. Processing and elaboration of data obtained by photogrammetric survey in Metashape (processing and elaboration of data elaborated by Sabrina Acquaviva and Marika Falcone).
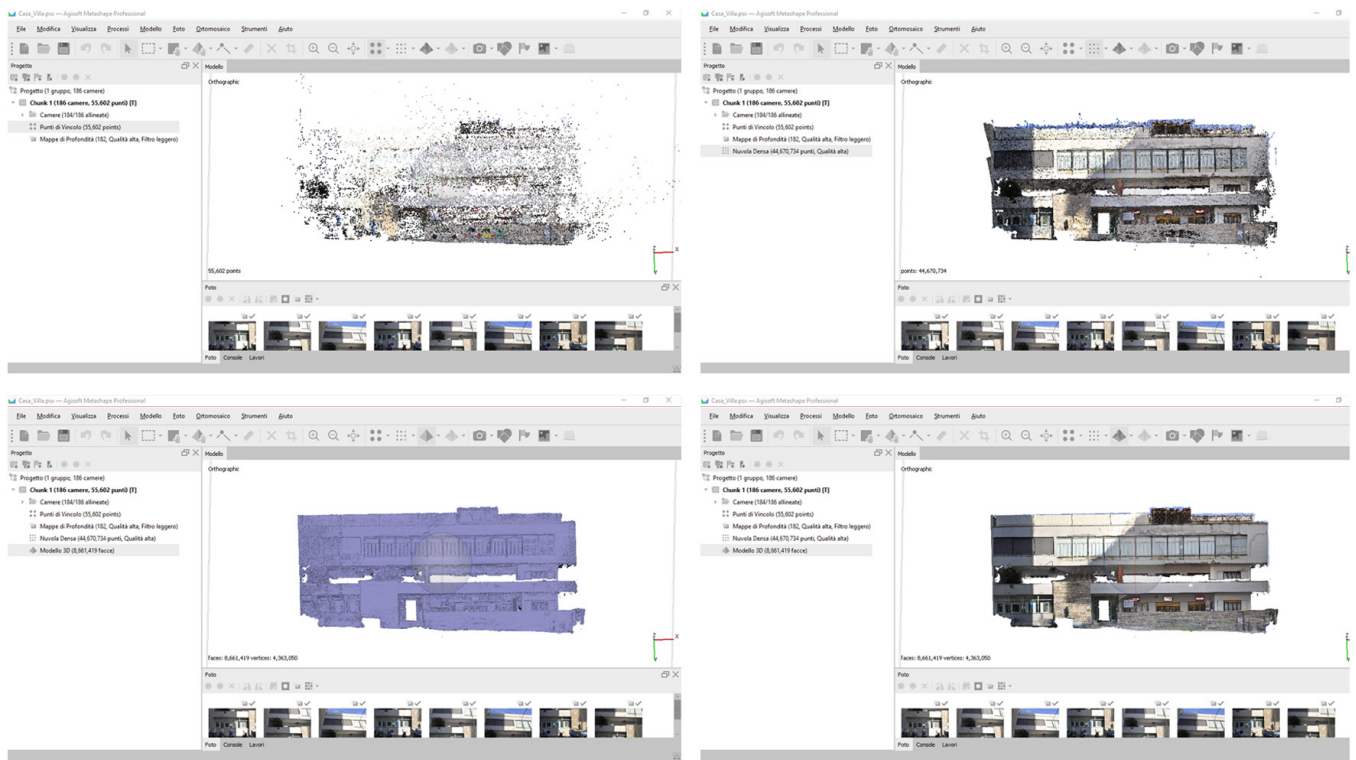

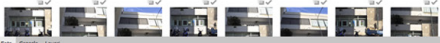

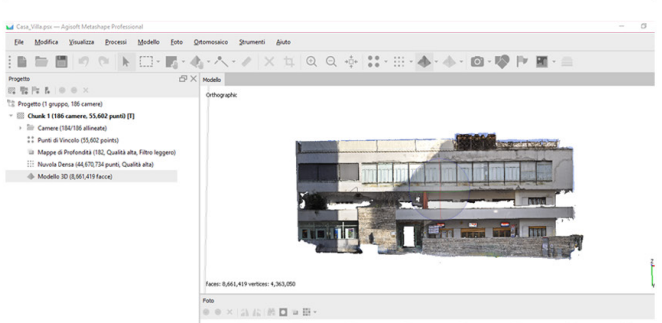

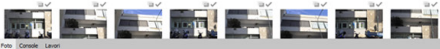

\section{Knowledge of the realized architecture}

The impossibility to find original drawings of Luigi Mustica or documentation that would allow to analyze the planimetric articulation of the building, in addition to the inaccessibility of private properties, have conditioned the study methodology which is limited to cognitive investigations of the only external configurations, favoring the study of the main facade. Integrated survey procedures, direct survey and terrestrial photogrammetric survey, have allowed the elaboration of useful figuration to explain the analyses and readings conducted. In the photogrammetric survey the recording of the metric and colorimetric information of the main facade was done with a Nikon D5000 camera, obtaining data set with overlap of $60 \%$ between frames. In relation to the limited shooting possibilities [5], it was decided to

Fig. 9. Casa Piscitelli, graphic restitution of main façade realized by Luigi Mustica in 1950. The figuration, synthesis and interpretation of the compositional characters of the project, is related to portions of orthophoto (raphic restitution to Acquaviva by Sabrina Acquaviva and Marika Falcone).

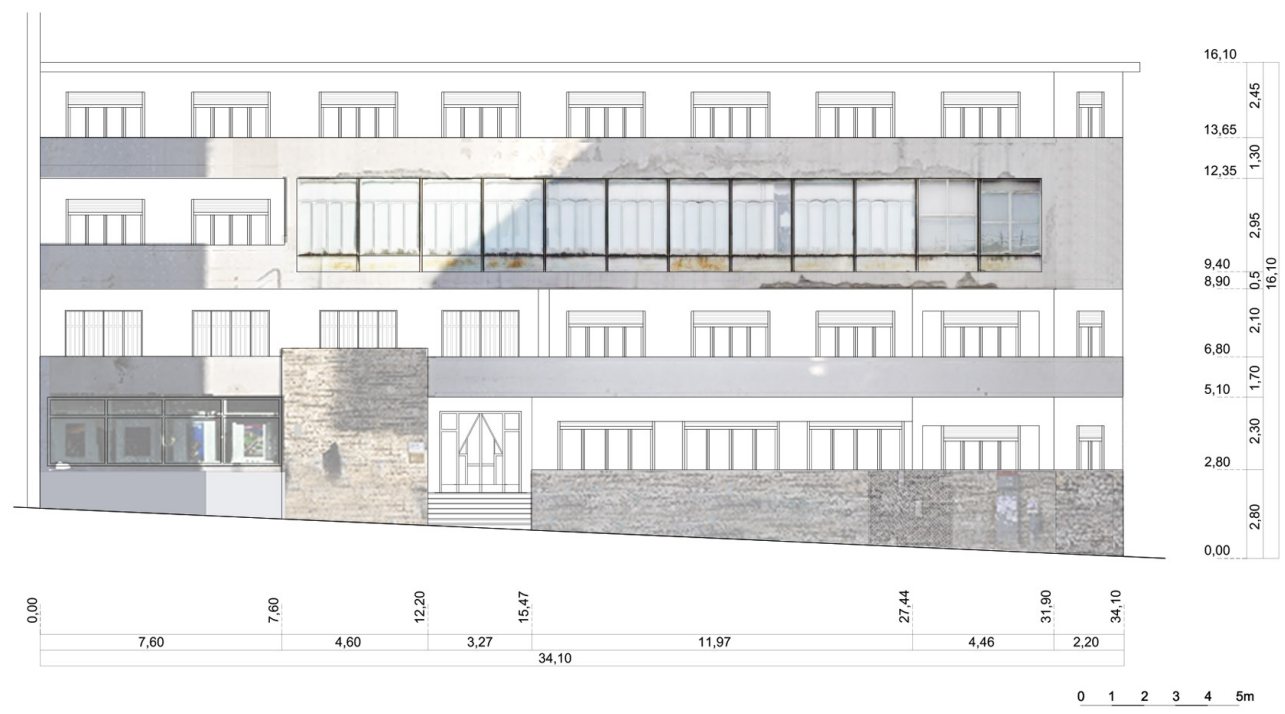


set the focal length to $24 \mathrm{~mm}$ respectively by photographic shooting technique both parallel for converging axes, thus recovering spatial information on different depth levels. The acquisition of photographic data sets has considered, among other things, the different lighting conditions of the front, to avoid areas strongly in the shadow, and to make automatic and more correct the data processing. The frames were processed, setting high quality parameters, using the software Agisoft Metashape. In the first processing phase the various frames were aligned in order to obtain the sparse cloud through homologous point recognition. Subsequently, points of cloud have been thickened (dense cloud) and the three-dimensional polygonal model was built (mesh), on which the photos were then projected for creation of the textured model. The orthophotos, processed by the three-dimensional point cloud, were used for the representation of the graphic designs through the discretization and interpretation of data [Remondino 20 I I].

The project of Mustica is divided into four above-ground levels, each one destined to host three apartments, and a basement used as a garage. If on the one hand the volumetric articulation of the whole is different from the previous solutions, on the other hand it confirms the desire to characterize the front with a solution of strong visual impact. Here the theme of the loggia, in the manner of Le Corbusier, characterizes both the main and the side facades. Another solution for which it is possible tracing parallel readings by unrealized projects, is represented by the drawing of the facing in uncertain stone of the base. Different plots and solutions emphasize the figures of the three bases. Chiaromonte imagines, on the main front, a low baseboard in stone whose continuity is broken by the basement windows. In addition, its height doubles on the back fronts due to the altitude jump imposed by the site. If in de Luca the base of the entire building is uniformly marked by the regular design of the travertine slabs, Mustica chooses to use only partially the stone facing to characterize two different parts: in the baseboard, which only concerns the base to a limited extent, and in the volume that realizes to connect the base and the upper level.
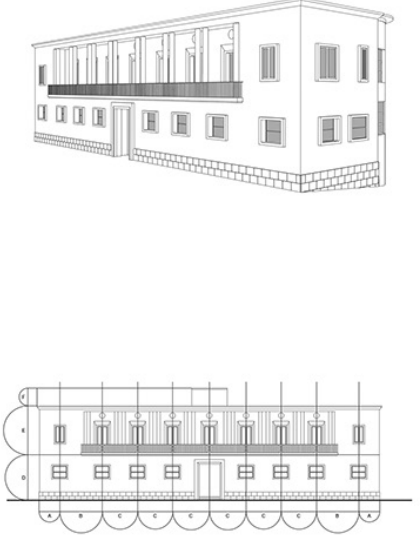

Fig. 10. The three projects in comparison through a graphic restitution elaborated by Giuseppe Volanti during his degree thesis; tutor prof. arch. Antonella

di Luggo, co-tutor arch. Daniela Palomba.

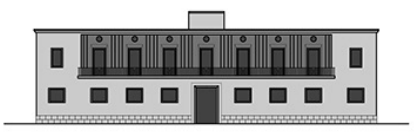

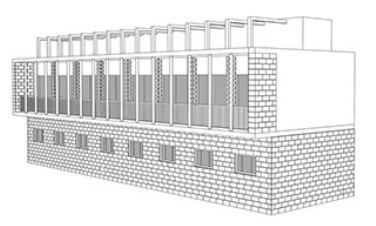
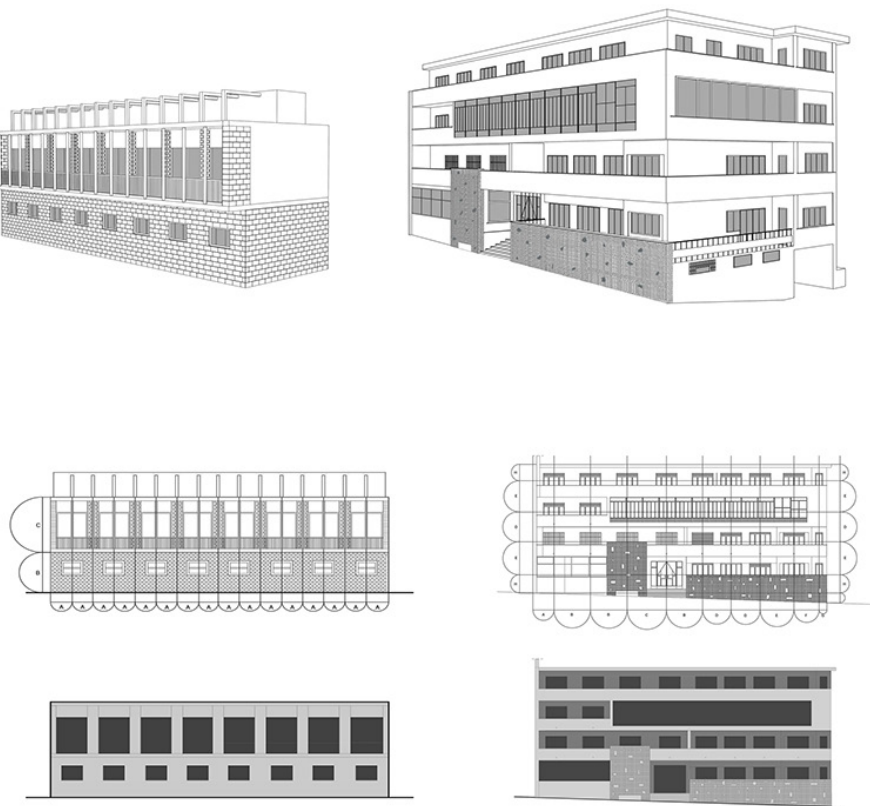


\section{Conclusion}

The theme of the comparison between the different interpretations of the same project suggests to identify and/or to verify possible relationships between ideas, to weave possible relationships, to recognize differences and similarities. These cognitive processes, when referred to architectures that no longer exist or never realized, can be realize thanks to the drawing, the existing iconographic documentation, then to be recounted and explained also through new figurations. The idea proposed is a tale in three stages, of three different figurations, in order to reveal the character compositional, linguistic and formal of the three different designers. The study of this architecture, Casa Piscitelli, has opened and projected to new dimensions that are not limited to the analysis of the project realized. Tracking the sources and investigate its history, suggests weaving three different moments. It is inevitable identify the bonds that the architecture weaves with the urban fabric in which it insists, but is even more stimulating to examine and investigate those non-visible relationships, those possible connections that only the careful reading of sources, original documentation, may reveal.

Fig. I I. Compositional and comparative analysis of main façade. Graphic restitution elaborated by Giuseppe Volanti during his degree thesis; tutor prof. arch. Antonella di Luggo, co-tutor arch. Daniela Palomba.
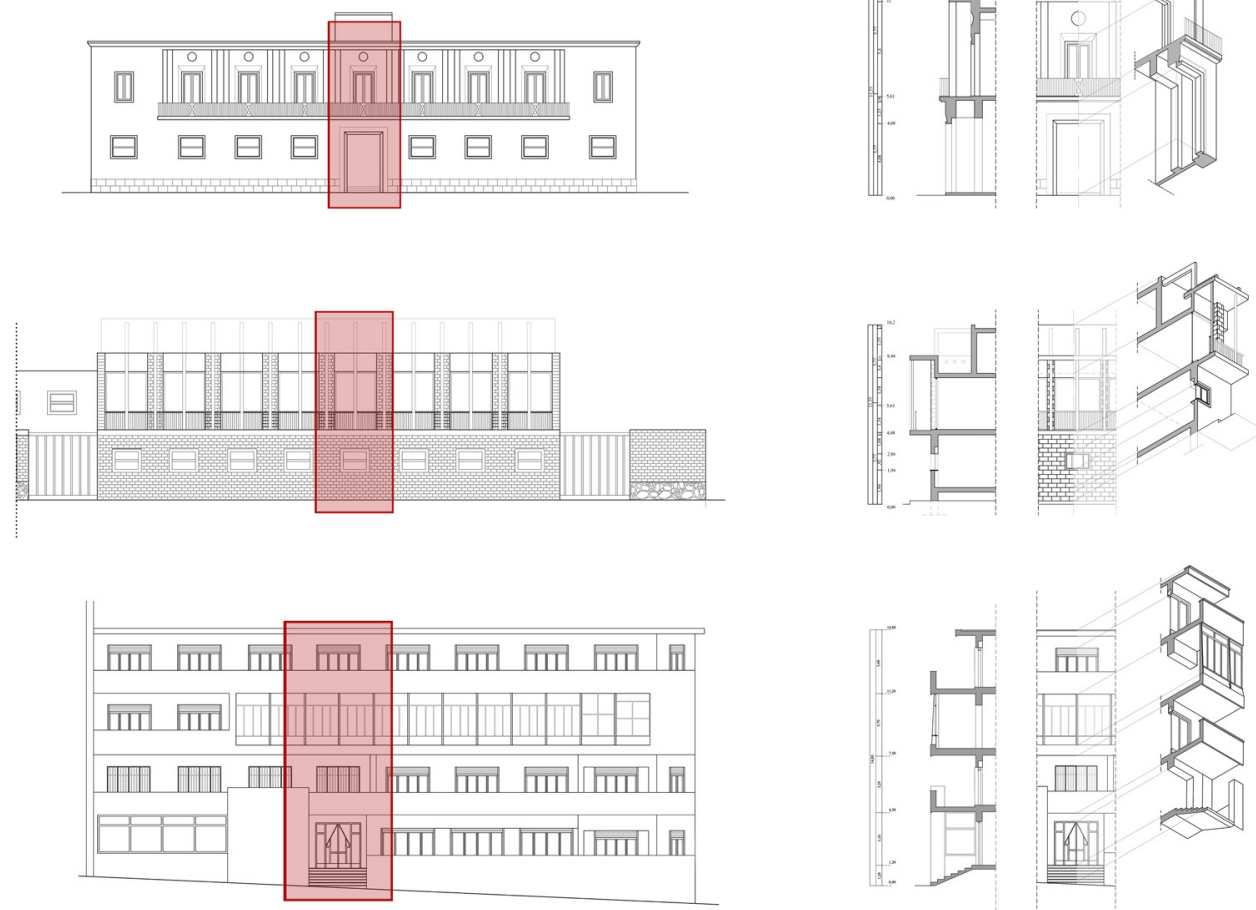

\section{Notes}

[I] As specified by di Luggo, there were several legal and administrative impediments that caused the postponed of construction of Casa Piscitelli to 1950. [Castagnaro, di Luggo 2008].

[2] In this figure the observer is allocated a zero quota. This perspective image is also compatible with a projection in which the object is placed on the horizon plane; This is the plane parallel to the geometry

[3] The project provided two apartments on the mezzanine floor and one of the largest size on the first floor.

[4] The staircase body is illuminated by a large window that crosses in height the entire building.

[5] The urban features of the site differ from the conditions in which the projects were devised even though the planning for the identification of the area was already known. 


\section{References}

Belfiore Pasquale, Gravagnuolo Benedetto (1994). Napoli. Architettura e Urbanistica del Novecento. Napoli: Laterza Roma-Bari. Bertoli Barbara (2013). Giulio de Luca 1912-2004. Opere e Progetti. Napoli: Clean.

Castagnaro Alessandro, di Luggo Antonella (2008). Ferdinando Chiaromonte. Disegni, opere, progetti. Napoli: Officina Edizioni. Castagnaro Alessandro (1998). Architettura del Novecento a Napoli. Napoli: Edizioni Scientifiche Italiane.

De Seta Cesare (1998). L'architettura a Napoli tra le due guerre. Napoli: Electra Napoli.

De Rubertis Roberto (1994). Il disegno dell'architettura. Roma: Carocci.

Mezzetti Carlo (2008). II disegno della palazzina romana. Roma: Edizioni Kappa.

Remondino Fabio (20 I I). Heritage Recording and 3D Modeling with Photogrammetry and 3D Scanning. In Remote sensing, 3(6), pp I 104-।|38.

Remondino Fabio et al. (2017). A critical review of automated photogrammetry processing of large dataset. In Int. Arch Photogramm in Remote Sens. Spatial Inf. Sci., XLII-2M5: 59I-599.

Ugo Vittorio (2008). Sulla critica della rappresentazione nell'architettura. Milano: Maggioli Editore.

\section{Authors}

Daniela Palomba, Università degli Studi di Napoli Federico II, daniela.palomba@unina.it

Sabrina Acquaviva, Università degli Studi di Napoli Federico II, s.acquaviva87@libero.it

Marika Falcone, Università degli Studi di Napoli Federico II, marique93@gmail.com

To cite this chapter. Palomba Daniela, Acquaviva Sabrina, Falcone Marika (2020). Connessioni temporali: lettura critica di un progetto in tre tempi/Temporal Connections: critical reading of a project in three times. In Arena A., Arena M., Brandolino R.G., Colistra D., Ginex G., Mediati D. Nucifora S. Raffa P. (a cura di). Connettere Un disegno per annodare e tessere Atti del $42^{\circ}$ Convegno Internazionale dei Docenti delle Discipline della Rappresentazione/Connecting. Drawing for weaving relationships. Proceedings of the 42th International Conference of Representation Disciplines Teachers. Milano: FrancoAngeli, pp. 2493-2514. 